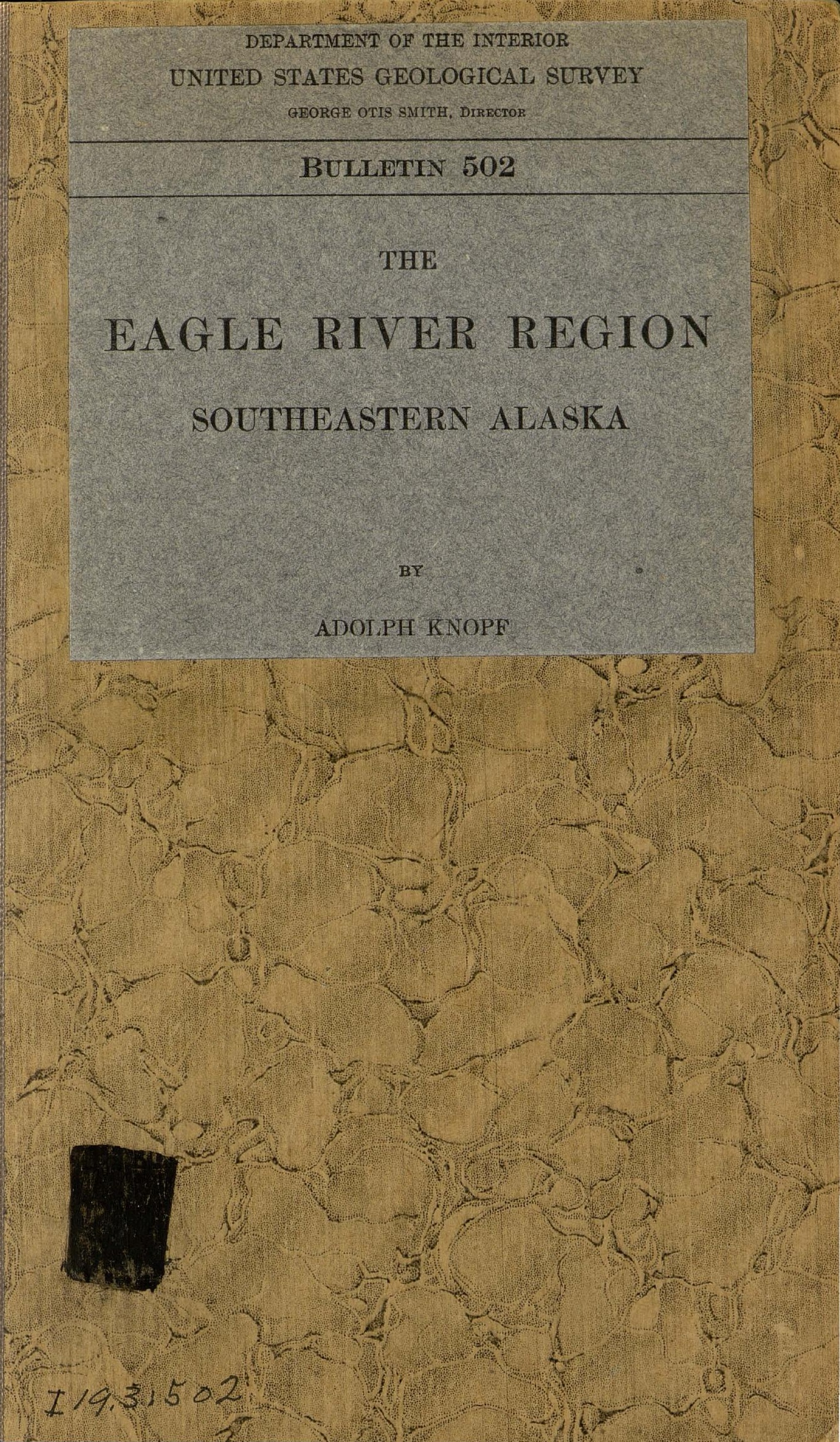



DEPARTMENT OF THE INTERIOR

UNITED STATES GEOLOGICAL SURVEY

GEORGE OTIS SMITH, DIRECTOR

Bulletin 502

THE

\section{EAGLE RIVER REGION}

\section{SOUTHEASTERN ALASKA}

BY

ADOLPH KNOPF

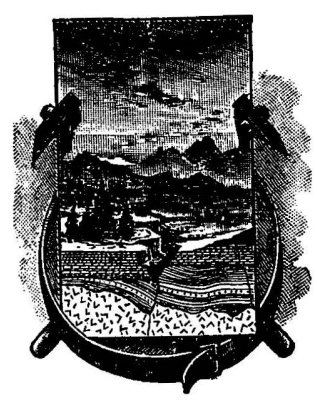

WASHINGTON

GOVERNMENT PRINTING OFFICE

1912 



\section{CONTENTS.}

Page.

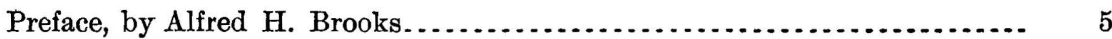

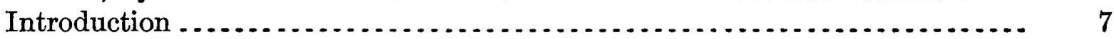

History and development.......

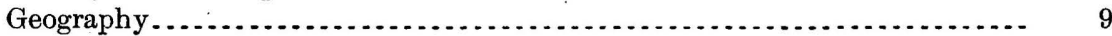

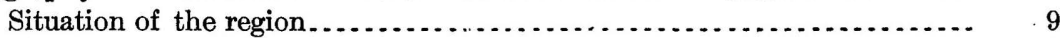

Physical features......

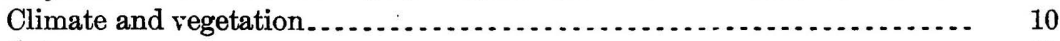

Glaciation ......

Outline of geology and ore deposits....

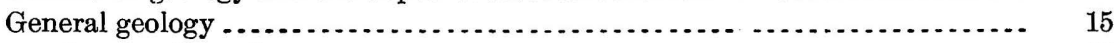

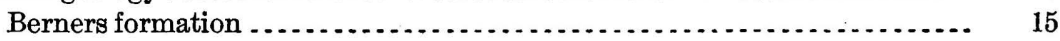

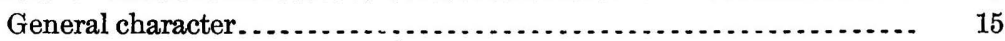

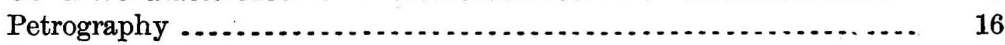

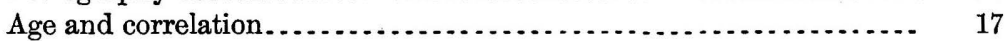

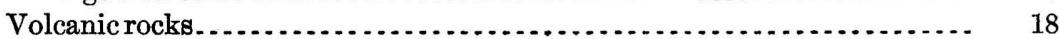

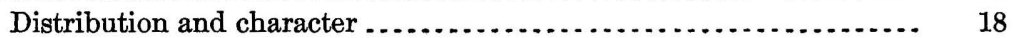

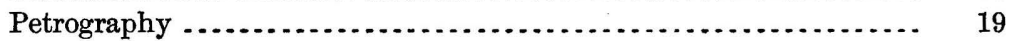

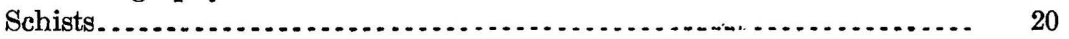

Occurrence and character . . . . .

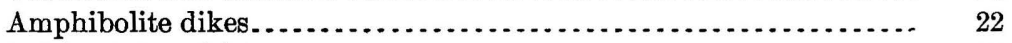

Origin of the schists. .........

Quartz diorite gneiss. ...

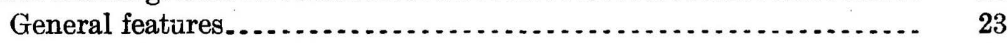

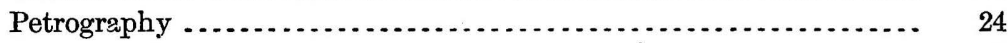

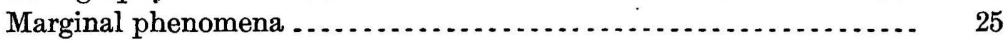

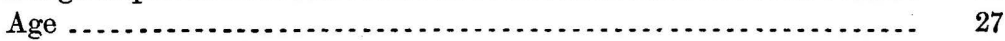

Minor intrusions and dikes..........

Albite diorite..........

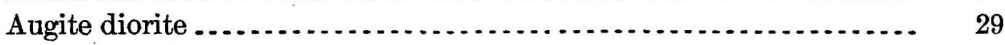

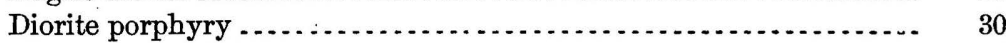

Lamprophyric dikes ...

Quaternary deposits ...

Economic geology ..............

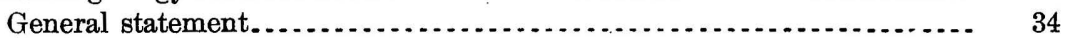

Stringer lodes ............

Fissure veins. . . .

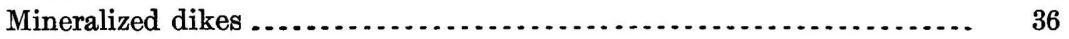

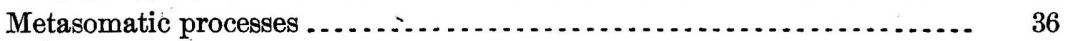

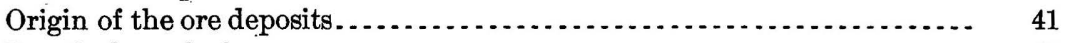

Practical conclusions......

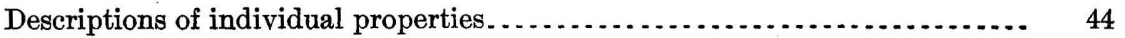

Eagle River mine. .................................... 44

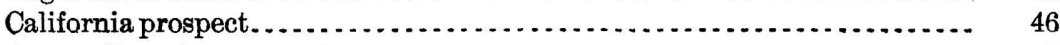

Aurora Borealis prospect...,n, 
Descriptions of individual properties-Continued. Page.

Bessie prospect................................................. 48

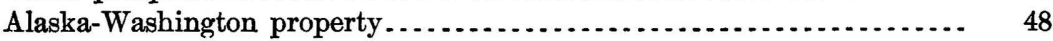

Yankee Basin prospects_........................................ 49

Canyon Creek prospects......................................... 50

Oleson prospect ................................................ 51

St. Louis and Summit claims................................... 52

Mitchell and McPherson prospect............................... 53

Peterson property............................................ 53

Montana Basin prospects...................................... 55

Treasury Hill claims......................................... 55

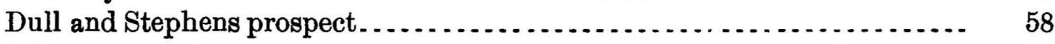

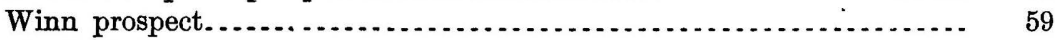

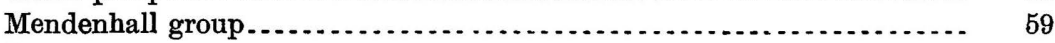

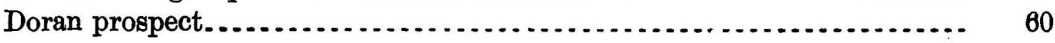

\section{ILLUSTRATIONS.}

Plate I. Topographic map of Eagle River area..................... In pocket.

II. Geologic map of Eagle River area........................ In pocket.

III. $A$, Goat Creek and Glacier; $B$, Head of Eagle River. . . . . . . . . . . 10

IV. Mendenhall Glacier ........................................ 12

V. Map showing distribution of ore deposits in the northern portion of the Juneau gold belt..................................... 34

FIGURe 1. Diagrammatic section along Dividend tunnel ................. 49

2. Diagrammatic section across strike at Prairie claim .............. 54

3. Claim map of Treasury Hill group......................... 56 


\section{PREFACE.}

\section{By Alfred H. Brooks.}

Southeastern Alaska was the first part of the Territory investigated as to its mineral resources by the Geological Survey, a study of the gold deposits of Juneau and Sitka having been made in 1895. ${ }^{1}$ For a few years after this most of the energies of the Survey that were applied to investigations in Alaska were directed to explorations in the interior. By 1901 these explorations were so far advanced as to justify a continuation of the investigations in southeastern Alaska, and a small allotment was made for a preliminary examination of the more important part of the Ketchikan district. ${ }^{2}$ Both these investigations were hasty and were chiefly valuable in furnishing information on which to base a more comprehensive plan of survey. Systematic surveys were begun in 1902 by the preparation of a detailed topographic base map of the gold-bearing area lying immediately adjacent to Juneau. Such a base map is essential to the accurate delineation of geologic formations, which in turn is necessary to a systematic study of the mineral resources. In 1903 the geology of the vicinity of Juneau was mapped in detail and a reconnaissance was made of practically the entire gold belt from Port Houghton northward to the international boundary, including the Porcupine gold placer district. In the following year a geologic reconnaissance of the accessible parts of Admiralty Island was made. In this work a large amount of time was devoted to the study of ore deposits, and in the reports ${ }^{3}$ special emphasis was laid on economic geology.

In 1905 similar reconnaissance work was carried southward to cover the Wrangell and Ketchikan districts. ${ }^{4}$ In the following year a geologic reconnaissance survey was carried northwestward

\footnotetext{
I Becker, G. F., Gold fields of southern Alaska: Eighteenth Ann. Rept. U. S. Geol. Survey, pt. 3, 1898, pp. 1-86.

2 Brooks, Alfred H., Preliminary report on the Ketchikan mining district, with an introductory sketch of the geology of southeastern Alaska: Prof. Paper, U. S. Geol. Survey No. 1, 1902, pp. 1-120.

${ }^{3}$ Wright, C. W., The Porcupine placer district, Alaska: Bull. U. S. Geol. Survey No.236, 1904. Spencer, A. C., The Juneau gold belt, Alaska: Bull. U. S. Geol. Survey No. 287, 1906, pp. 1-137. W Wight, C. W., A reconnaissance of Admiralty Island, Alaska: Tdem, pp. 138-154.

4 Wright, F. E. and C. W., The Ketchikan and Wrangell mining districts, Alaska: Bull. U. S. Geol. Survey No. 347, 1908, pp. 1-210.
} 
from Lynn Canal to Lituya Bay. ${ }^{1}$ Between 1906 and 1908 some work was also done in the Sitka district. Meanwhile detailed mapping had not been neglected. In 1906 a topographic survey of the Berners Bay region was completed, and in 1907 and 1908 similar surveys were made of the Kasaan Peninsula and Copper Mountain regions, both on Prince of Wales Island, in the Ketchikan district. The geologic mapping and the study of ore deposits of the two districts last named were completed in $1909,{ }^{2}$ though unfortunately the final report ${ }^{3}$ has not been completed.

The geologic work in the Berners Bay region was done in $1910 .{ }^{4}$ It still remained to connect this area with the area surveyed in detail near Juneau. This was accomplished in 1909 and 1910, when both the topographic and the geologic survey of this important gold-bearing district were made. The results of these surveys are here set forth. In 1910 a part of the Sitka district ${ }^{5}$ was also reexamined.

The above review indicates that during the last decade much has been accomplished in the systematic survey and investigation of the geology and mineral resources of southeastern Alaska. The total land area of this province aggregates nearly 40,000 square miles, less than half of which has been covered by geologic reconnaissance maps. The broken character of the coast line affords good exposures, which are readily accessible, but the inland regions are exceedingly difficult to traverse and, except in the high ranges, afford but few rock exposures. Over much the larger part of the province the geology is complex and can be deciphered only by detailed mapping. These facts should be taken into account by those who may be led to think that the results have been meager for the expenditure of time and money. If many important geologic problems remain unsolved, yet much has been learned of the occurrence and distribution of the mineral deposits. It is to this end that the work has been chiefly directed.

Circumstances over which the writer has had no control have long delayed the preparation of the final reports on some of the investigations above chronicled. Meanwhile all the important economic conclusions have been made public in the summary reports on the progress of investigations published every year since 1904.

\footnotetext{
1 Wright, F. E. and C. W., A geologic reconnaissance of the Glacier and Lituya Bay regions; Bull. U. S. Geol. Survey. In preparation.

2 Wright, C. W., Mining in southeastern Alaska: Bull. U. S. Geol. Survey No. 379, 1909, pp. 74-82.

B Wright, C. W., The geology and mineral resources of the Kasaan Peninsula and Copper Mountain regions, Ketchikan district, southeastern Alaska: Bull. U. S. Geol. Survey. In preparation.

4 Knopf, Adolph, Geology of the Berners Bay region, Alaska: Bull. U. S. Geol. Survey No. 446, 1911, pp. 1-58.

5 Knopf, Adolph, The Sitka mining district, Alaska: Bull. U. S. Geol. Survey No. 504.
} 


\title{
THE EAGLE RIVER REGION, SOUTHEASTERN ALASKA.
}

\author{
By Adolph Knopf.
}

\section{INTRODUCTION.}

The Eagle River region, as defined in this report, includes the northern portion of the Juneau gold belt, extending northwestward from Salmon Creek, a few miles northwest of Juneau, to Berners Bay. This strip of territory is 32 miles long and embraces nearly a third of the entire length of the gold belt.

Since the original discovery of gold in 1880 at Gold Creek the Juneau gold belt has produced $\$ 50,000,000$, but the bulk of this sum has come from the immediate vicinity of Juneau, and largely from the Treadwell group of mines. At present the mining activity of the gold belt centers at Juneau and at Berners Bay; the intervening territory, which is here named the Eagle River region, contains a large number of prospects under exploration, but is still essentially in an undeveloped state; south of Juneau but little work is in progress.

The investigation described in the present report completes the detailed study of the geology and ore deposits of the northern portion of the Juneau gold belt. This study was commenced in 1903 by A. C. Spencer, who made a careful investigation of the region in the immediate vicinity of Juneau, mapping the geology on the scale of 1 mile to the inch, and in the same year, with the aid of $\mathrm{C}$. W. Wright, made a rapid reconnaissance of the whole belt. ${ }^{1}$ The results of these investigations, especially of the thorough examination of the ore bodies at Juneau, have been of great assistance in the study of the problems arising during the present investigation of the region north of Juneau. In 1909 a geologic examination of the Berners Bay region was made by the writer, and the report on this work has already been published. ${ }^{2}$

Field work in the Eagle River region occupied parts of the seasons of 1909 and 1910-from July 10 to September 14, 1909, and from July 7 to September 9, 1910. Approximately 200 square miles was covered during the periods stated. The region contains many features of great geologic interest, but during the present investigation atten-

1 Spencer, A. C., The Juneau gold belt, Alaska: Bull. U. 8. Geol. Survey No. 287, 1906.

2 Knopf, Adolph, Geology of the Berners Bay region, Alaska: Bull. U. S. Geol. Survey No. 446, 1911. 
tion was restricted essentially to the broader features of the distribution of the rock formations and to studies of the ore deposits. A brief preliminary account of the geology and mineralization has already been published. ${ }^{1}$

\section{HISTORY AND DEVELOPMENT.}

The earliest operations in the region were those of placer miners at the heads of Montana and Windfall creeks in 1882. Old wingdams, ditches, and bowlder piles show where the pioneers labored; but as the beds of the streams are choked with huge blocks of diorite their efforts yielded a bare wage only, and attempts at placer mining by primitive methods were soon abandoned. Later, about 1900, hydraulic plants were installed to wash the gravels near Windfall Lake, on McGinnis Creek, and on Lemon Creek, but they did not prove successful. On Lemon Creek the ground was tested with Keystone drills in 1904, and no work has been done since then. ${ }^{2}$

The first discoveries of auriferous rock in place were made also in 1882, and claims were staked at Montana Basin and near Auke Lake. Prospecting has continued intermittently, occasionally stimulated to greater activity by encouraging discoveries. The discovery of the Eagle River lode in 1902 and the construction of a 20-stamp mill on the property in 1903 were of much importance to the district.

New discoveries are made from time to time, and as late as 1908 extensive quartz outcrops were uncovered not far from the point where the old trail to the placer workings crosses the summit between Auke Bay and Montana Creek. To those familiar with the region such discoveries occasion no surprise. Throughout the inland portion of the gold belt outcrops below timber line are effectually buried under several feet of glacial drift, which is itself covered by a heavy growth of moss and vegetation, and these features and the wet climate make prospecting difficult and onerous. It is therefore to be expected that occasional discoveries will continue to be made, aided, as they have been in the past, by the overturning and uprooting of trees and by landslides, which from time to time bring to light new exposures of bedrock.

The state of development of the region in 1903 was described by Spencer ${ }^{3}$ and that in 1905 by Wright. ${ }^{4}$ The development since then has been far less rapid than was expected at that time. Many causes have combined to retard the progress of the mining industry, among them litigation and inflated valuation; but the principal

1 Bull. U. S. Geol. Survey No. 480, 1911, pp. 103-111.

2 The geology of these deposits has been carefully described by A. C. Spencer in Bull. U. S. Geol. Survey No. $287,1906$.

B Bull. U. S. Geol. Survey No. 287, 1906, pp. 117-134.

Bull. U. S. Geol. Survey No. 284, 1906, pp. 34-37. 
cause is the low grade of the ores. Large capital is necessary to open the properties, and investors usually demand a more thorough development of the ore bodies than has so far been made in most places. At Juneau, where the ore bodies are near a center of population, the formulation and adoption of plans for working the large low-grade gold deposits on a scale proportionate to their magnitude has required many years, and it is only recently that these plans have been approaching achievement.

The production of the region, with the exception of a few thousand dollars, has been the output of a single mine at Eagle River, which has been in operation since 1903.

\section{GEOGRAPHY.}

\section{SITUATION OF THE REGION.}

The gold belt consists of a narrow strip of country lying between salt water and the high diorite peaks of the Coast Range. Its general trend is northwest and southeast, parallel to the coast. The length of the belt as measured from Salmon Creek, which is 3 miles northwest of Juneau, to Berners Bay, on the north, is 32 miles. The width ranges from 4 to 5 miles. (See Pl. I, in pocket.)

Gastineau Channel and Lynn Canal bound the region on the southwest. Berners Bay, a broad indentation from Lynn Canal, in latitude $58^{\circ} 42^{\prime}$ north and longitude $135^{\circ}$ west, bounds it on the northwest. It is therefore easily accessible by water. In winter, however, often for weeks at a time, the fiords are not safe for small craft during stormy weather.

Juneau is the supply point of the region. The head of Gastineau Channel is a broad mud flat at low tide, and passage over "the bar," as it is locally known, is possible only at high tide, and then only for vessels of light draft. Luarger craft are forced to go around the south end of Douglas Island. Local steamers plying on a six-day schedule between Juneau and Skagway call regularly at Eagle Landing, on Lynn Canal. Freighters also call here for concentrates to be shipped to the Tacoma smelter.

A well-built Government trail, made during the summer of 1909 and 1910, traverses the length of the belt and connects Juneau with Amalga, where a post office is maintained. This trail renders the extreme inland portion of the gold belt somewhat more accessible than it has been in the past, but for the transportation of heavy freight from Juneau the waterway is far more serviceable. The economical development of any mining property in the belt necessitates the building of a tramway to the nearest harbor, and such tramways have been built at places where any important operations have been undertaken. 


\section{PHYSICAL FEATURES.}

The region is notable for its abrupt topographic features. (Pl. III, $A$ and $B$.) The ruggedness increases greatly toward the northeast, where the numerous glaciers and precipitous relief make the mountains nearly inaccessible. Between Lynn Canal and this impassable mountainous background, whose altitude ranges from 4,000 to 6,000 feet, lies a belt of country composed of parallel ridges attaining an elevation of 3,000 feet and trending parallel to the coast and to the underlying bedrock structure. The ridges show smooth and rounded profiles in contrast to the pinnacles and crags of the region to the northeast. Along the coast they rise steeply from the water's edge, so that ingress to the interior of the gold belt is restricted to the few places where passes break through the mountains near harbors.

The drainage of the region is mainly parallel to the bedrock structure. This is particularly true of Montana, Windfall, and Cowee creeks, whose valleys form in effect a single system traversing the length of the belt. The larger streams; like Eagle, Herbert, and Mendenhall rivers, which are of glacial origin, flow in wide gravelfloored valleys across the general trend of the belt. They are swift streams, carrying large volumes of water during the summer months, but sinking to a low minimum during the winter months.

\section{CLIMATE AND VEGETATION.}

The climate is cool, equable, and humid, and is characterized by a large number of cloudy and rainy days. During the summer stormy weather is rare, but during the winter strong and protracted gales blow down the fiords. An adequate idea of the general climatic features can be obtained from the data collected at Juneau by the Weather Bureau.

Climatic data for Juneau.

\begin{tabular}{|c|c|c|c|c|c|c|c|c|c|c|c|c|c|}
\hline & Jan. & Feb. & Mar. & Apr. & May. & June. & July. & Aug. & Sept. & Oct. & Nov. & Dec. & $\begin{array}{c}\text { An- } \\
\text { nual. }\end{array}$ \\
\hline $\begin{array}{l}\text { A verage maximum } \\
\text { temperature, }{ }^{\circ} \mathrm{F} . .\end{array}$ & 32.9 & 34.3 & 39.8 & 47.6 & 55.9 & 62.7 & 64.6 & 61.4 & 55.6 & 48.3 & 40.5 & 35.9 & 48.3 \\
\hline Average minimum & & & & & & & & & & & & & \\
\hline $\begin{array}{l}\text { temperature, }{ }^{\circ} \mathrm{F} . \\
\text { Average tempera- }\end{array}$ & 24.2 & 24.2 & 28.7 & 34.8 & 40.8 & 46.3 & 49.6 & 48.2 & 44.0 & 38.1 & 30.3 & 27.2 & 36.4 \\
\hline $\begin{array}{l}\text { ture........... } \\
\text { Maximum temper- }\end{array}$ & 28.5 & 29.3 & 34.3 & 41.2 & 48.4 & 54.5 & 57.4 & 54.8 & 49.8 & 43.2 & 35.5 & 31.9 & 42.4 \\
\hline ature............ & 50 & 51 & 61 & 63 & 80 & 84 & 88 & 82 & 74 & 68 & 60 & 60 & 88 \\
\hline $\begin{array}{l}\text { ature.......... } \\
\text { a verage rainfall, }\end{array}$ & -10 & -4 & -5 & 13 & 24 & 31 & 38 & 36 & 31 & 20 & -1 & 1 & -10 \\
\hline inches........... & 7.87 & 4.75 & 4.86 & 5.58 & 5.40 & 3.97 & 4.53 & 7.08 & 11.16 & 10.14 & 8.54 & 7.24 & 81.12 \\
\hline $\begin{array}{l}\text { A verage snowiall, } \\
\text { inches............ } \\
\text { Average number of }\end{array}$ & 32.9 & 23.1 & 11.7 & 4.8 & 0 & 0 & 0 & 0 & 0 & 1.3 & 6.6 & 30.1 & 110.5 \\
\hline $\begin{array}{l}\text { days with pre- } \\
\text { cipitation........ }\end{array}$ & 17 & 12 & 14 & 18 & 16 & 13 & 14 & 17 & 20 & 21 & 19 & 19 & 200 \\
\hline
\end{tabular}




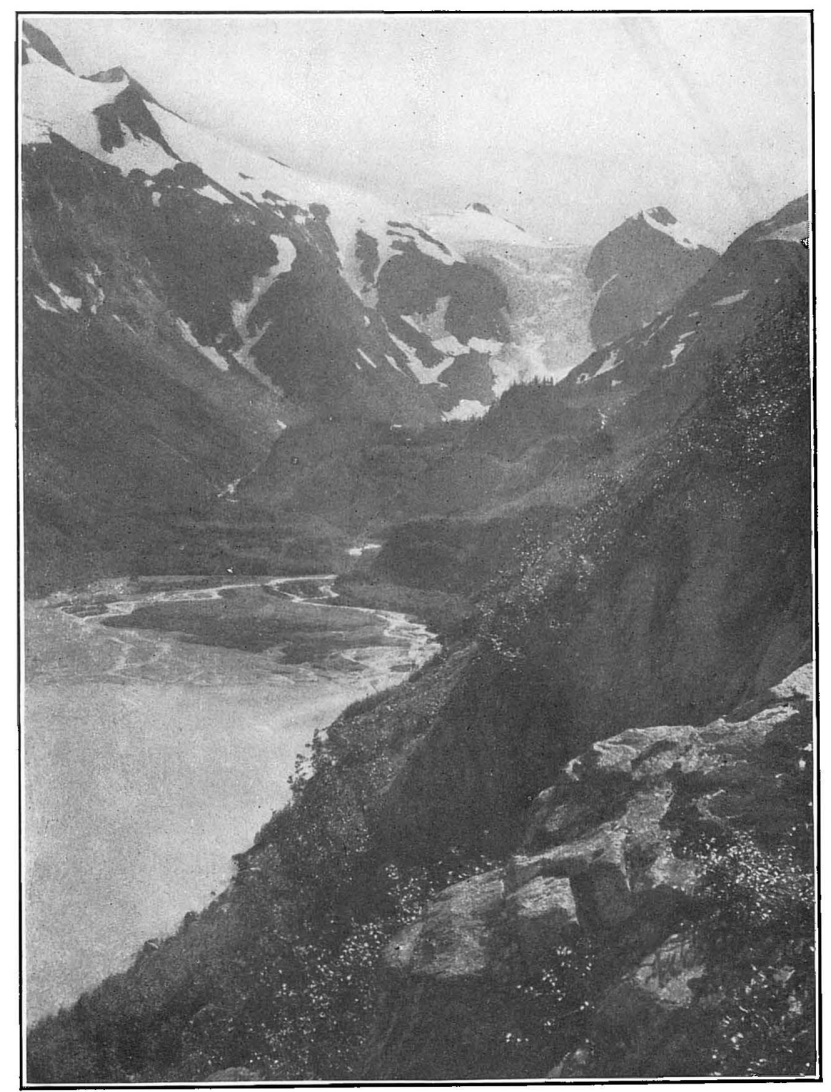

A. GOAT CREEK AND GLACIER LAKE.

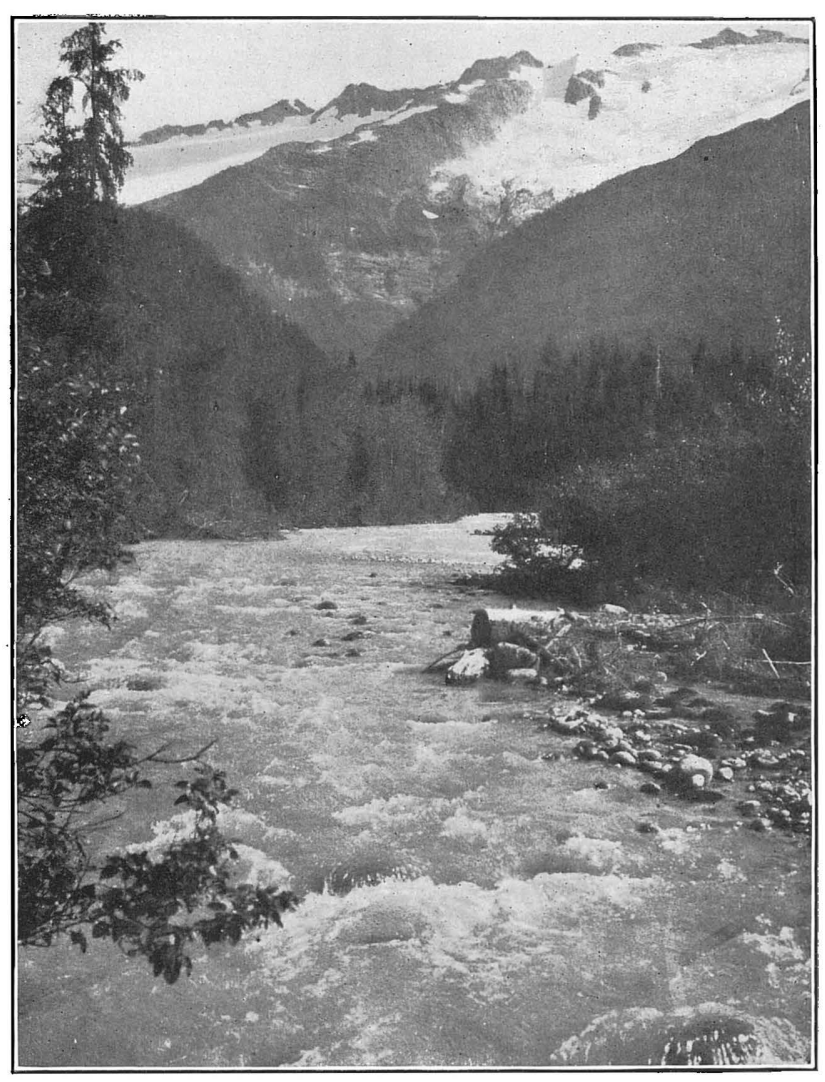

B. HEAD OF EAGLE RIVER. 

The precipitation, as shown by the table, is heavy. This furnishes a resource of considerable importance to the mining industry in the shape of water power, which is utilized in large measure near Juneau, where approximately 9,000 horsepower has already been deviloped. Although the catchment basins of the streams are small, yet because of the extensive snow fields at higher altitudes, the rapid run-off, and the frequent rainfall, the volume of water carried by the streams is disproportionately large. On the other hand, because of the rapid run-off an unusual period of drought in late summer, say of 10 days' duration, is likely to cause the plants that are unprovided with storage facilities to run short of water.

At the present time the Treadwell Co. is developing the water power of Nugget Creek by the erection of a dam 125 feet high at the mouth of the lower basin. Water rights are held by other claimants on Lemon and McGinnis creeks. ${ }^{1}$

The region is forested with spruce and hemlock, which extend up to altitudes of 2,500 feet. Pine grows in isolated stands in the open grassy parks, which are apparently too wet for the other conifers. Cedar was found only on the ridge southeast of the mouth of Nugget Creek. Spruce and hemlock are the only trees of economic importance; spruce is in most demand. The supply is adequate for general mining purposes. The best timber grows in protected localities in valley bottoms; the finest trees are found in the lower part of the valley of Lemon Creek, where one tree was seen that is 170 feet high and 6 feet in diameter at 6 feet above the ground. As a rule, the average stand of timber ranges somewhat below 2 feet in diameter. The deep covering of moss and the rank, luxuriant undergrowth are pervading features of the forest. Blueberry brush, devil's club, and the alders along the streams are particularly common. In some places a dense growth of young hemlock, standing among a plexus of prostrate windfallen trunks, forms impenetrable thickets. These features render prospecting difficult and geologic examination impossible.

\section{GLACIATION.}

Three large glaciers flow out from the recesses of the Coast Range, descending to altitudes of 100 feet above sea level, but do not reach tidewater by severai miles. They are admirably shown and contoured on the topographic map accompanying this report (Pl. I, in pocket), and the positions of the fronts have been accurately fixed so that any future changes of importance due to advance or retreat can be readily determined. There are a few other but smaller glaciers in the area shown on the map and many to the northeast of this area.

\footnotetext{
1 For a discussion of the possibilities of water-power development in southeastern Alaska, see Hoyt, J. C., A water-power reconnaissance in southeastern Alaska: Bull. U. S. Geol. Survey No. 442, 1910, pp. 147-157.
} 
'The large glaciers have the sloping fronts characteristic of retreating glaciers; they are also nearly free of morainal material carried on their leacks, a feature due in part to their shrunken condition. Retreat of the glaciers is indicated by the bare glaciated bedrock along their sides not yet covered by the rapidly advanoing vegetation and by claim stakes of prospectors, which a few years ago were placed as near the ice as possible, but are now several hundred feet distant from it.

The largest glacier in this region is Mendenhall Glacier, which is shown in Plate IV. It is fronted by an extensive plain, $2 \frac{1}{2}$ miles wide, underlain by gravel consisting largely of well-rounded cobbles of diorite, averaging 5 inches in diameter. Sporadic blocks 10 to 15 feet long rest on the plain, which is diversified by some morainal ridges on which spruce trees are growing. Near the front of the glacier some stream channels incised 12 feet or so beneath the general level of the plain have partly exhumed a buried forest, as indicated by stumps of trees, some of which are 32 inches in diameter. These facts point to a complex series of oscillations, but data are not available from other glaciers in the vicinity to corroborate this inference. At Glacier Bay, however, an extensive forest, covered by heavy deposits of gravel, has been exposed by the retreat of the glaciers.

Davidson ${ }^{1}$ presents some evidence showing that between 1892 and 1901 the front of Mendenhall Glacier retreated at the rate of 40 to 50 feet a year.

The present glaciation is visibly linked with a past glaciation of vastly greater extent, which at its flood period covered the area of the gold belt with ice. The evidence of former glacial occupation of the region is to be seen everywhere. Diorite blocks brought out from the core of the Coast Range lie scattered throughout the region up to altitudes of 3,400 feet; glacial till covers much of the bedrock, and where bedrock is unoovered it is polished and marked with glacial scorings. Roche moutonné topography is found on divides at altitudes of 2,500 feet, and the broader features of glacial sculpture have determined the general topographic aspect of the entire region.

At the flood period, then, a great ice stream having a thickness, measured from present sea levei, of 3,400 feet, or a total of approximately 5,000 feet, moved down Lynn Canal, overflowing its channel and burying the gold belt under ice. To this overriding sheet the topography of the belt owes its rounded character, in contrast with the pinnacled region to the northeast.

According to the theory of glacial erosion the ice stream in Lynn Canal should have established a base level for ice erosion 3,500 feet above present sea level as a datum plane. It is therefore a problem

1 Davidson, George, Trans. and Proc. Geog. Soc. Pacific, 2d ser., vol. 3, 1904, p. 79. 


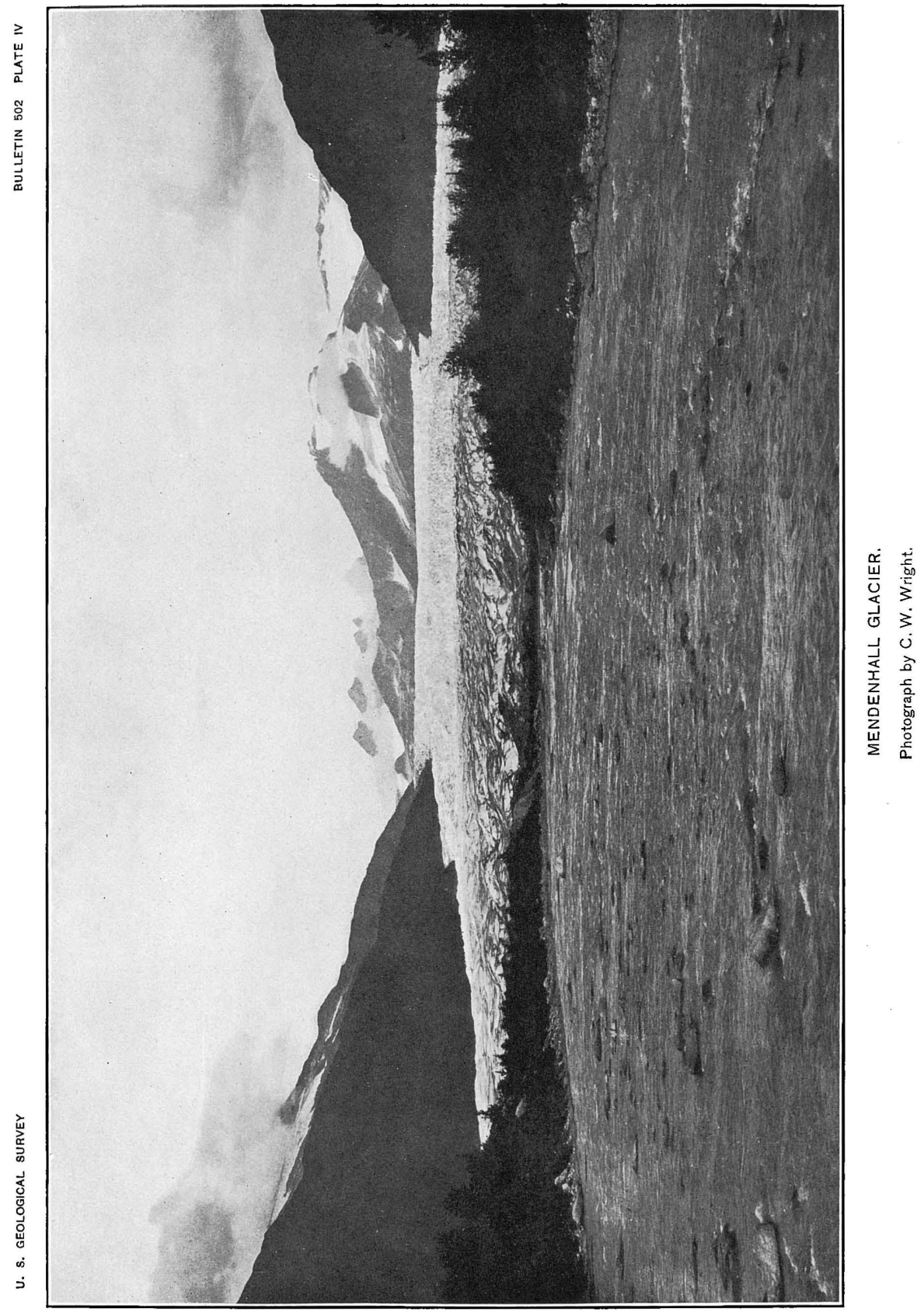



of some interest why the troughs of the transverse tributaries, such as those of Berners, Eagle, and Mendenhall rivers, are not hung up high above the bottom of Lynn Canal. The hanging character may possibly have been obliterated by the persistence of glacial ice in the tributaries long after the great ice stream had withdrawn from the trough of Lynn Canal; or, on the other hand, the fiords of southeastern Alaska, instead of being due to enormous glacial erosion; may be due to the drowning of an adjusted drainage system somewhat modified by glacial erosion. Some probability is lent to the second alternative by the fact that the Juneau region is definitely known to have been uplifted in postglacial time at least 200 feet (see p. 33); farther west, at Controller Bay, evidence has been obtained showing that there the late Quaternary submergence amounted to at least 1,000 feet." Although Controller Bay lies several hundred miles northwest of Juneau, the facts ascertained with regard to it make a certain caution imperative in interpreting the late Quaternary history of the Juneau region.

\section{OUTLINE OF GEOLOGY AND ORE DEPOSITS.}

The rocks are arranged in belts that strike parallel to the general trend of the gold belt and dip steeply to the northeast. The general parallelism of stratification, cleavage, schistosity, gneissic foliation, dikes, intrusive masses, and ore bodies is the salient geologic feature of the region.

The larger part of the gold belt is underlain by an interstratified series of slates and graywackes, with some conglomerates. This assemblage of sedimentary rocks, together with intercalated masses of volcanic rocks, has been named the Berners formation, because it is well exposed across the strike on both shores of Berners Bay and because paleontologic proof of its age was found there. Fossil plants, consisting chiefly of ferns, indicate that the formation is of either Upper Jurassic or Lower Cretaceous age. The older view that the rocks of the Juneau gold belt are of Carboniferous age therefore needs modification. It is probable that the rocks of the productive part of the belt are mainly of late Mesozoic age.

The volcanic rocks associated with the slates and graywackes, which are usually known as greenstones, consist of lavas, flow breccias, tuffs and coarse breccias, conglomerates, and various kinds of mixed rocks. The clastic material far exceeds the massive rock in bulk. The lavas are in many places extremely amygdaloidal and display a striking ellipsoidal structure, indicating that they were probably erupted into water. These volcanic rocks, which are clearly

1 Martin, G. C., Geology and mineral resources of the Controller Bay region, Alaska: Bull. U. S. Geol, Survey No. 335,1908, p. 64 . 
of late Mesozoic age, possess a distinctive appearance and petrographic character, sufficient, it is believed, to distinguish them from other volcanic greenstones of the Juneau gold belt. They are characterized by the widespread prevalence of numerous well-formed and wellpreserved porphyritic crystals of augite embedded in a close-grained matrix of dark blue-green color. To signalize tinis feature they are termed augite melaphyres. The volcanic greenstones of the Juneau gold belt, formerly regarded as belonging to a single period, are now known to contain extrusives of Carboniferous and of late Mesozoic age and are found to have distinct petrographic characteristics. By metamorphism the augite melaphyres are converted into actinolite schists.

Toward the northeast the slates and graywackes pass gradually into phyllites and schists, which become progressively more and more crystalline toward the diorite gneiss that forms the northeast boundary of the gold belt. The schists where they adjoin the gneiss are garnetiferous, staurolitic, cyanitic, and coarsely biotitic. In places they are remarkably contorted, as is well shown on the polished surfaces along the glaciers. The width of the schist belt decreases from several miles at Lemon Creek to several hundred feet at Berners Bay.

The gneiss on the northeast, which in local usage is known as the granite hanging wall of the Juneau gold belt, is the crushed and foliated margin of the great intrusive quartz diorite core of the Coast Range. The gneissic structure is best developed near the contact with the schists and fades out northeastward into the ordinary structure of normal granitic rocks. It is essentially a cataclastic effect which was produced by the crushing of the component minerals of the quartz diorite and which was impressed on the diorite soon after the rock had consolidated from fusion. In fact, a period of dynamic deformation set in during the pegmatitic stage, for some of the pegmatite and aplite dikes are sheared like the gneiss, but others have escaped the general dynamic metamorphism. The sedimentary rocks adjoining the gneiss have recrystallized into schists, whose crystallinity, as already stated, diminishes gradually from the contact. The region thus affords an illustration of a belt of crystalline schists of late Mesozoic age formed as an effect of the heat and pressure accompanying a great batholithic intrusion.

A considerable number of dikes, generally lying parallel to the structure of the inclosing rocks, are found in the slates, and range from light-colored diorite porphyries to dark basic rocks of gabbroic composition. The sequence in time of the various kinds is not well known, as they are rarely found intersecting one another.

The ore bodies are exclusively gold deposits. The greater number are stringer lodes, but they include some mineralized dikes and a few 
fissure veins. Nearly all the ore bodies lie within the belt of slates and graywackes - a fact of distribution which seems to have determined their character as stringer lodes. Except for sporadic shoots of rich ore, the stringer lodes are of low grade. They range in width from a few feet to 100 feet and apparently, at a few prospects, to 300 or 400 feet. The greatest depth attained anywhere in the district hardly exceeds 200 feet.

Some of the mineralized dikes are of economic importance; all are of considerable interest in that the profound alterations which they have undergone throw light on the character of the solutions that brought in the gold. A common change is a large introduction of albite, which is shown to be a regional feature of the Juneau gold belt. Other changes consist in the introduction of apatite into the altered wall rocks and the conversion of amphibole into biotite. From these and other features the vein-forming waters are believed to have been hot, ascending solutions of deep-seated origin, probably connected with the intrusion of the diorite magma.

Whatever oxidized products may have existed in the past have been largely removed by the recent glacial erosion; this fact, together with the similarity in origin of the deposits to those at Juneau, whose behavior in depth is known, renders it highly probable that the gold content found near the surface will persist downward without essential change of value.

\section{GENERAT, GEOLOGY.}

\section{BERNERS FORMATION (UPPER JURASSIC OR LOWER CRETACEOUS).}

\section{GENERAL CHARACTER.}

The most important rocks in the region are an interstratified series of clay slates and graywackes which have been named the Berners formation because they are typically exposed at Berners Bay. ${ }^{1}$ Rocks of volcanic origin, usually known as greenstones, are also included in the formation, but the larger areas, underlain essentially by the greenstones, are separately shown on the geologic map under an appropriate symbol. Toward the northeast the slates and graywackes grade into schists, which are also shown under a separate symbol. The Berners formation forms a long belt trending northwest and southeast, which contains nearly all the mineral deposits of the region.

At Berners Bay the graywackes are intimately interstratified with the slates. The beds of graywacke are not persistent along the strike but are lenticular and interdigitate with the slates. Crossbedding is finely developed at same places, and some beds are slightly conglomeratic, containing small well-rounded pebbles. The gray-

1 Bull!. U, S. Geol. Sưrvey No, 446, 1911, pp. 14-17, 
wackes are massive and do not show the cleavage characteristic of the associated argillite strata.

Toward the south the graywackes become less abundant and in the territory south of Eagle River they are comparatively scarce. At Auke Bay they are practically absent and the rocks consist almost wholly of fissile black clay slates, which are of roofing-slate quality, unlike those at any other locality in the gold belt. The maximum thickness of individual strata of graywacke, so far as observed, is 80 feet.

The general strike of the rocks is northwest and southeast, and the dip is almost everywhere to the northeast, at angles ranging from $20^{\circ}$ to vertical but most commonly $40^{\circ}$ to $60^{\circ}$. Only local dips to the southwest are found, as in the belt of graywacke and slate intercalated in the volcanic rocks between Eagle River and Yankee Cove. In places the rocks are acutely folded and the axes of flexure also are folded so that they range from a horizontal to a vertical attitude within short distances, but no evidence of broader and more extensive folding, which undoubtedly exists, was procured. The cleavage of the rocks is generally parallel to the stratification, but local discrepancies occur.

\section{PETROGRAPHY.}

The graywackes are gray or greenish-gray rocks of roughly schistose or massive structure. The fresh material taken from mine openings has a black color due to finely disseminated carbonaceous matter; that taken from natural exposures is gray or mottled gray, having been bleached by the action of the sunlight. The graywackes are far harder rocks than the soft slates interstratified with them-a fact readily recognizable to those who have conducted mining operations in this formation. They are composed largely of grains of plagioclase feldspar and quartz, together with fragments of other minerals and rocks, embedded in an argillaceous cement. The composition is somewhat variant; at Berners Bay, for example, the graywackes contain considerable augite and hornblende derived from it, so that hand specimens might be mistaken for tuffs or even for porphyries. As a rule, however, none of the constituents, except the glassy grains of quartz and the fragments of black slate, are recognizable by the eye.

With increase of argillaceous material in the graywackes the cleavage approaches in perfection that of the interbedded clay slates. Such roeks should be called graywacke slates. On cross-fractured surfaces some of them show only numerous glistening particles of quartz embedded in an aphanitic matrix, imparting to them a porphyritic appearance. Rocks of this kind and the coarser graywacke slates are common in the region near the Eagle River mine and the head of Canyon Creek. 
Conglomeratic graywacke was seen at only one locality within the gold belt, north of Echo Inlet, where it forms a belt several hundred feet wide. Outside of the region conglomerate and conglomeratic graywacke are known on Portland Island, on Douglas Island near Outer Point, and at Point Young on Admiralty Island.

Under the microscope the graywackes are found to consist largely of altered fragments of plagioclase feldspar; north of Berners Bay they contain little or no quartz, but south of the bay quartz becomes more prominent. The composition, however, varies; some of them contain considerable augite, probably of pyroclastic origin; others contain none. The rock fragments also vary in number and kind, but, except the slate particles, they are commonly well rounded.

It will be apparent from the foregoing description that at some localities it may be difficult to distinguish the graywackes from tuffs; this difficulty becomes pronounced near the volcanic areas.

\section{AGE AND CORRELATION.}

Evidence as to the age of the Berners formation was obtained only at Sawmill Cove, on the east side of Berners Bay. This evidence consists of a small collection of plants, chiefly ferns, found in 1909 and determined by F. H. Knowlton to be of Jurassic or Lower Cretaceous age, with the probability in favor of their being Jurassic. ${ }^{1}$ On the basis of this determination the writer correlated the Berners formation with a belt of Aucella-bearing rocks found by C. W. Wright on Admiralty Island and regarded as of Lower Cretaceous or possibly. Upper Jurassic age.

Subsequent examination of the rocks at Point Young and Portland Island, which are stated to form the northwestern extremity of the Aucella-bearing terrane, leaves no doubt as to the correctness of the correlation. The rocks at Point Young consist of clay slates, graywackes, and conglomerates, and contain a few dikes and sills or flows of green amygdaloidal augite melaphyre. In lithology, in degree of metamorphism and dynamic disturbance, and in the presence of igneous rocks typical of the Berners formation there is complete identity between these rocks and those of the mainland. The problem, therefore, resolves itself into a question of the identity of the rocks at Point Young with those from which the Aucellas were collected at Pybus Bay. ${ }^{2}$

According to the writer's view, the rocks of the northern part of the Juneau gold belt are mainly of Jurassic or Lower Cretaceous age. Spencer, on the other hand, regarded the whole belt as Carboniferous, on account of the presence of fossils of that age in limestones found

1 Bull. U. S. Geol. Survey No. 446, 1911, p. 17.

2 Bull. U. S. Geol. Survey No. 287, 1906, p. 144.

$17883^{\circ}-$ Bull. $502-12-2$ 
at Taku Harbor, a small embayment 25 miles southeast of Juneau. It is one of the unsolved problems of the region whether the Carboniferous rocks extend north of Taku Inlet; if they do, they are probably complexly infolded with the younger rocks.

The rocks at Taku Harbor have not been described petrographically, although they have been carefully examined from a paleontologist's point of view. ${ }^{1}$ As this locality contains one of the two points at which the age of the formations of the gold belt is definitely known, it seems worth while to present a brief description of the rocks found there. The fossiliferous beds consist of bluish-gray to nearly black marbles, interstratified with welded limestone breccias. The calcareous rocks are associated with phyllite and green schists, showing an abundant development of micaceous minerals. A few miles farther south, at Limestone Inlet, are a series of surface volcanic rocks-amygdaloids and breccias-which are roughly schistose and show finely disseminated biotite on their foliation planes. Notable among these is a porphyry showing prominent tabular phenocrysts of feldspar; examined microscopically, they prove to be microcline microperthite phenocrysts embedded in a trachytoidal groundmass of albite laths interspersed with considerable flaky biotite. No rocks of this character have been found in the known Jurassic portion of the gold belt. Farther south, at Snettisham, there is a zoisite amphibolite which shows a nearly obliterated porphyritic texture, suggesting that it has been derived from a basalt porphyry.

It is therefore apparent that the rocks associated with the known Carboniferous strata are much more highly metamorphosed than the normal Jurassic rocks, and, furthermore, that the volcanic greenstones of the Carboniferous differ markedly from the younger volcanic greenstones, which are highly pyroxenic lavas and breccias. At present three series of volcanic rocks can be recognized among the greenstones of the Juneau gold belt-the basaltic amygdaloids of the Berners Bay region, whose relations are not satisfactorily determined, the Jurassic augite melaphyres, and the Carboniferous andesites and more salic lavas.

\section{VOLCANIC ROCKS.}

\section{DISTRIBUTION AND CHARACTER.}

Masses of volcanic rocks, locally known as greenstone but here termed augite melaphyres, occupy scattered areas throughout the belt of graywackes and slates. They range in size from single narrow sheets, which represent both interbedded lava flows and intrusive sills, up to broad belts several miles long. The most persistent development of rock of this kind is along the shore of Lynn Canal from 
Point Bridget to Auke Bay, and as shown by Spencer's map the southward extension forms the backbone of Douglas Island.

The volcanic rocks include lavas, flow breccias, tuffs, coarse breccias (agglomerates), conglomerates, and mixed rocks, such as tuffaceous conglomerates. The pyroclastic and clastic material far exceeds the lavas in bulk. Stratified volcanic breccias form massive exposures along the east shore of Tee Harbor. In texture they range from fine to coarse. Some of the coarser breccias inclose angular blocks exceeding a foot in diameter, and some of the finertextured beds show lenses of coarser material. At many localities conglomerates are intimately associated with the breccias. The pebbles consist essentially of volcanic material and range up to wellrounded bowlders 2 feet in length; but subangular and angular fragments are found and the matrix is either tuffaceous or consists of reworked material of volcanic derivation, so that it is impossible at many places to discriminate conglomerates from breccias.

All these rocks are thoroughly indurated and are among the hardest and firmest of the region. Clay slates are interstratified with the tuffaceous beds at some places, and it is a general feature that beds of igneous material alternate with normal sedimentary rocks near the margins of areas underlain by rocks dominantly of volcanic origin. On the geologic map only the larger areas have been delimited, and because the greenstones and slates alternate along the margins and dovetail along the strike the boundaries of these belts have of necessity been drawn somewhat arbitrarily.

The strike is northwest and southeast; the dip ranges from $20^{\circ} \mathrm{NE}$. at Auke Bay to vertical at Bridget Cove. The bulk of the rocks show little or no schistose structure, especially in the belt fringing the coast, but toward the northeast dynamic deformation becomes in creasingly prominent. As a rule sheets, otherwise massive, that are intercalated in the slates are highly schistose along their contacts.

A considerable volume of breccia is inclosed in the schist belt at Herbert Glacier and has been converted into amphibolitic rocks.

\section{PETROGRAPHY.}

The color of the augite melaphyres and related rocks is commonly some shade of green, which becomes more and more pronounced according to the degree of metamorphism that the rocks have undergone. They are therefore usually spoken of as greenstones, but the use of that term is avoided as far as possible in this report, because its employment leads to confusion in a region in which it is equally applicable to a large number of other rocks. The less altered and better-preserved lavas are of dark greenish-blue to bluish-black color and resemble basalts in appearance. The characteristic feature of 
all these rocks, of both the massive and the clastic varieties, is their unfailing content of augite. In the massive varieties augite forms numerous well-preserved phenocrysts of sharply idiomorphic development and of dark vitreous brown-green color. Porphyritic feldspars are notably absent. At some localities the augite phenocrysts make up half the bulk of the rock. Macroscopically, then, the rocks are dark-colored porphyries containing augite phenocrysts and are therefore augite melaphyres according to the descriptive field classification of Pirsson. It has been found advisable to retain this designation as a geologic term.

In places the lavas are extremely amygdaloidal, the amygdules being filled with calcite and chlorite, as along the coast from Yankee Cove to Bridget Cove, or inland in the volcanic belt south of Amalga. That the amygdaloidal character, however, is no proof of surface origin is shown by the fact that an 8-foot dike of augite melaphyre filled with calcite amygdules traverses conglomerate and graywacke at Point Young, on Admiralty Island.

Between Yankee and Bridget coves the lavas display a remarkable development of ellipsoidal structures, which are finely shown on the sea cliffs and shore exposures. The largest ellipsoids are 8 feet long and several feet in diameter; at points of contact they show mutual indentation. The outer shell of any ellipsoid is denser textured and the amygdules in it are much smaller than those in the central part which is coarsely amygdaloidal. Under the microscope the rock is found to be made up of numerous augite phenocrysts embedded in a groundmass consisting largely of matted augite microlites; the small amount of interstitial space between the augite prisms is filled with a feebly birefringent material showing shadowy extinction and an index of refraction below that of Canada balsam. The amygdules are filled with spherulitic chlorite, calcite, and orthoclase, which is here and there plumose. The only observable difference in rock composing the interior and the exterior of the ellipsoids is that the augite microlites of the groundmass in the interior portion are stouter and better individualized. These lavas are therefore the extrusive forms of a highly pyroxenic magma and, as shown by their ellipsoidal structure, were probably erupted under water.

SCHISTS.

OCCURRENCE AND CHARACTER.

A belt of schists lies between the slate-graywacke formation and the great mass of gneissic quartz diorite lying to the northeast. It ranges in width from 2 miles at Mendenhall Glacier to a few hundred feet at Berners Bay. Outlying masses of schist are embedded in the gneiss and lie parallel to the main belt and to the foliation of the gneiss. 
The schists comprise a variety of rocks, mainly of original sedimentary derivation, and show a considerable diversity of mineralogical make-up. Biotite, garnet, and amphibole are the most common minerals of metamorphic origin that are easily distinguishable, and of these biotite is by far the most abundant and widespread. Staurolitic schists are found in which the staurolite prisms lie embedded as prominent crystals along the foliation planes, as at the head of Windfall Basin. A fine example of cyanite schist is found on the ridge between Nugget and Lemon creeks.

Coarsely crystalline white limestone is interstratified with the schists in beds ranging up to 50 feet in thickness, but is not particularly abundant and is restricted to the outlying masses of schist in the gneiss, except in the headwaters of Nugget and Lemon creeks, where it is found in the main belt. The limestone is nearly pure, commonly carrying as an accessory a little biotite or specular hematite, or both together, and rarely some pyroxene. As other rocks obviously of sedimentary origin may be mentioned some thin-bedded quartzites found in the region south of Mendenhall Glacier.

Along the southeast side of Herbert Glacier a large volume of augite melaphyres and related rocks is included in the schist belt. On glaciated surfaces it is effectively brought out by weather tinting that some of these rocks were originally volcanic breccias or subangular conglomerates. The shapes of the fragments are well shown, and the fragments differ from one another in that some are more thickly studded with augite phenocrysts than others. In some the augite phenocrysts are drawn out and deformed, being apparently converted to scaly aggregates of biotite; in others they are remarkably well preserved. One of the more schistose varieties-a heavy green schist showing numerous elongate patches of black mineral on the foliation planes-was found under the microscope to consist largely of fibrous actinolite, with about 10 per cent of biotite, mostly localized in the metamorphosed phenocrysts, and epidote, and an unimportant amount of feldspar.

In many places, as shown on the broad polished surfaces of bedrock exposed along the sides of the retreating glaciers, the schists are remarkably contorted, so that they exhibit the features formerly regarded as diagnostic of the Archean. The general strike of the foliation and stratification is parallel to the structural trend of the gold belt. The schists are most highly crystalline in the zone directly bordering the quartz diorite gneiss, but toward the southwest they grade through phyllites and biotitic slates into the clay slates and graywackes of the next adjoining belt of rocks. In fact, the boundary between the schists and the slate-graywacke formation was arbitrarily fixed by determining the first appearance of visible flakes of biotite in the rocks as the gneiss is approached 
across the strike. There is, as a rule, an ambiguous zone here, and it is not uncommon to find an alternation of beds of normal clay slate with fine-grained schist showing small flakes of biotite on the cleavage planes. Toward the northeast, near the gneiss, the biotite becomes coarser and more plentiful and the heavy porphyritic minerals appear, especially garnet and staurolite.

Of the purely microscopic features of the schists the most interesting is the practically complete absence of cataclastic phenomena. The porphyritic garnets, the staurolite prisms, the cyanite prisms, and the long plates of biotite are undeformed; the quartz in the quartzite exists as large interlocking grains optically homogeneous and unstrained. This freedom from dynamic disturbance contrasts strongly with the crushed character of the adjoining quartz diorite gneiss.

Along the contact of the schist belt and the gneiss an extensive interlayering of schist and gneiss is encountered; part of the gneiss bands are readily recognizable as of igneous origin-offshoots from the main mass of quartz diorite gneiss that were intruded parallel to the foliation of the schists. Crosscutting dikes are extremely rare. In places the sedimentary rocks were coarsely recrystallized, injected with numerous dikelets parallel to the foliation planes, and pegmatized so that their original characteristics are entirely obliterated.

\section{AMPHIBOLITE DIKES.}

Some dikes of amphibolite are found in the schist belt in the vicinity of Mendenhall Glacier and in the region to the south. They conform to the general structure and are persistent for many miles.: Near Juneau they are mineralized and contain valuable ore bodies, but father north they have not proved to be of economic importance. Spencer ${ }^{1}$ has shown that they were derived from gabbros.

They contain considerable hornblende, which in the coarser-textured dikes is arranged in sheaf-like and radial groups, and to the abundance of this mineral they owe their dark color. Single dikes are likely to exhibit a considerable variety in appearance, as is well shown in the dike exposed below the mouth of Nugget Creek. This dike, which is several hundred feet wide, rests on a footwall of thinbedded quartzites and has a schistose structure parallel to the stratification of the quartzites. The lower portion of the dike is a crushed granitoid rock in which the hornblende is in places noticeably radial; toward the top the texture becomes porphyritic, with feldspar forming the phenocrysts; and in the uppermost portion the dominant effect is porphyritic, with numerous zoisitized or epidotized feldspars resting in a dark, nearly black schistose matrix consisting largely of hornblende. 


\section{ORIGIN OF THE SCHISTS.}

The field relations are believed to establish clearly that the belt of schists is a metamorphic phase of the Berners formation. The facts that make this deduction unavoidable are, briefly restated, first, the alternation of slate and schist along the border, evidently due to the different susceptibility of interstratified beds to metamorphism; second, the presence of characteristic lithologic types, such as the augite melaphyre breccias; and third, the progressive increase of crystallinity in the schists as the gneiss is approached, culminating in a zone in which metamorphic minerals of high density are developed in porphyritic fashion.

The cause of the metamorphism is to be sought in the heat and pressure accompanying and following the intrusion of the great quartz diorite batholith. The dynamic disturbances following the irruption left their unmistakable impress upon the diorite, but the schists recrystallized under conditions of essential quiescence.

\section{QUARTZ DIORITE GNEISS.}

GENERAL FEATURES.

Quartz diorite gneiss bounds the gold belt on the northeast and forms the rugged mountains of the interior of the Coast Range. In distant views the gneiss presents the appearance of a stratified formation, owing to the fact that it spalls in great blocks parallel to the gneissic structure. As a whole it maintains a remarkable uniformity of appearance and composition from Berners Bay to Taku Inlet, and in all probability it extends with the same uniformity even farther southeast.

The quartz diorite gneiss consists essentially of a coarsely granular assemblage of clear vitreous striated feldspar, quartz, biotite, and hornblende, all of which are easily recognizable by the unaided eye. Toward the contact with the schist belt on the southwest the grain becomes somewhat finer in texture over a width commonly of several hundred feet. According to local usage the quartz diorite is termed a granite, which is sufficiently accurate for general purposes, but it differs from granite in that orthoclase, which is commonly the dominant constituent of granite, is nearly or entirely lacking.

The gneissic structure of the quartz diorite, like the foliation of the adjoining schists, trends northwest and southeast and dips steeply to the northeast, at about $70^{\circ}$. It is in part a primary structure assumed by the magma during solidification but is mainly a result of dynamic metamorphism, the most obvious effect of which has been the reduction of the large feldspar crystals to augen. In a few places the feldspars were sufficiently crushed and drawn out to form narrow white bands. The foliation of the gneiss is most 
pronounced near the contact, where it is in places so strongly developed as to form a black diorite schist carrying porphyritic eyes of feldspar; toward the northeast the gneissic structure gradually and progressively gives way to the massive granular texture characteristic of normal granitic rocks. Viewed in the large this gneissic border, which forms a belt from 1 to 2 miles or more wide, constitutes the foliated margin of the quartz diorite core of the Coast Range. This axial mass of granitoid rocks is 50 miles wide in this latitude and extends uninterruptedly for a thousand miles northward from southern British Columbia. At Skagway and at the upper end of Taku Inlet it is found that the batholith is of composite origin and that more salic rocks were intruded subsequently to the quartz diorite; in the area considered in this report only the quartz diorite gneiss is encountered, and it has been mapped under that designation to signalize an important feature in the geology of the region.

Because few lodes have been found in the quartz diorite gneiss, it is said in local speech to form the hanging wall of the Juneau gold belt.

\section{PETROGRAPHY.}

The general macroscopic features of the quartz diorite have already been pointed out. In addition to the essential minerals, the presence of sporadic crystals of yellow titanite is characteristic. The feldspars range from 3 to 10 millimeters in longest dimension. In the gneissic phases cataclastic phenomena are obvious in hand specimens and are chiefly expressed in the augen character of the feldspars. It is probable that the minerals composing the diorite were roughly oriented during the crystallization of the magma, for the coarse prisms of hornblende lie in the plane of the gneissic structure, although disposed in random orientation within this plane. The tabular feldspars also show a similar rough tendency toward parallel orientation. Under the microscope the feldspars are found to be peripherally crushed and to have their corners rubbed off; the quartz to be reduced to granulation mosaics; the biotite, and to a less extent the hornblende, to be sliced and to wrap around the feldspar augen. The gneissic structure is therefore essentially due to the deformation of the quartz and ferromagnesian minerals, which was superimposed upon a rough parallel orientation produced during consolidation. In specimens from different localities the feldspars range from $A b_{40} A n_{60}$ to $A b_{70} A n_{30}$, probably averaging near $A b_{50} A n_{50}$, which is slightly more calcic than that found at Berners Bay. Zonal banding is a pronounced feature of the feldspars. Orthoclase is rare or absent. Biotite and hornblende in approximately. equal amounts. 
constitute the dark minerals. Titanite is an abundant accessory mineral, apatite and magnetite occur less abundantly, and zircon is very rare. Secondary minerals, such as epidote, chlorite, and sericite, are practically absent. A rough estimate would place the feldspar content at 60 per cent, quartz 20 per cent, and biotite and hornblende together 20 per cent.

\section{MARGINAL PHENOMENA.}

Various modifications of the quartz diorite gneiss are found along the contacts with the main schist belt and with the outlying bands of schist. The most common change, as already alluded to, is the passage from the coarse-textured, imperfectly oriented gneiss of gray color to a dark, closely foliated, fine-grained gneiss. Locally, as on the northwest side of Herbert Glacier, the hornblende becomes segregated so as to form a coarse hornblendite in which the interstices between the hornblende prisms are filled with biotite and pyrrhotite. At most places along the contacts the schists are extensively injected with dioritic dikes. The dikes have a gneissic structure and lie parallel to the foliation and stratification of the schists, conforming to the folding; in places this interlayering of schist and gneiss is so thorough and the metamorphism of the schist by recrystallization and pegmatization so complete that it is impossible to discriminate diorite from schist. Belts of such ambiguous rocks attain a considerable width and are commonly banded and laminated with mathematical evenness and precision.

On the east side of Berners Bay, where the exposures are good and easily accessible, the gneiss incloses for thousands of feet from the contact vast numbers of rock fragments and detached masses of stratified sediments. It is worthy of note that all such detached masses of original country rock, wherever found in the gneiss, are oriented parallel to the prevailing structure, and that where they show crumpling the crumpling is conformable to the wrinkled foliation of the inclosing gneiss. The conclusions that follow from these facts are, first, that the magma crystallized under an oriented pressure which was able to align the fragments of country rock disrupted from the walls of the batholithic chamber during intrusion, and, second, that subsequent to the consolidation of the magma the continuance' (or renewal) of the work of this force produced the widespread cataclastic effects to which the gneissic structure appears to be largely due.

In the border zone of the gneiss and in the adjoining belt of schists are found dikes of white granitoid rocks, mostly of the kinds usually referred to aplite and pegmatite. They are not common in the region north of Mendenhall Glacier, but become numerous south of the glacier in the headwaters of Nugget and Lemon creeks. Here, where 
the schist belt is particularly wide, they are found as far as 2 miles from the contact.

The dikes in the quartz diorite follow the gneissic structure, show macroscopic evidence of crushing, and display an imperfect foliation, so that it is clear that some of them were injected prior to the main gneissic deformation. Many of those intruded between the foliation planes of the schists are remarkably folded, but some that are apparently folded break across minor crumples and inclose contorted fragments of schist. On the northwest side of Lemon Glacier, at an altitude of 1,600 feet, a dike of pegmatite 10 feet thick pierces the folds in the inclosing schist and a distinct drag of the strata can be seen to have taken place along the walls of the dike.

These various facts, apparently conflicting among themselves, require the interpretation that the pegmatites and other salic rocks were intruded during a period of continuous dynamic activity.

The composition of the dikes is varied, but the presence of a plagioclase feldspar, andesine or labradorite, rather than orthoclase, and the occurrence of garnets, some of which form idiomorphic crystals up to a hazelnut in size, are general features. Other minerals noted are quartz, muscovite in coarse plates, biotite, microperthite, and tourmaline in black columnar groups. On the whole, tourmaline is rare in this region. In thin sections the quartz is seen to be greatly granulated, and myrmecitic intergrowths of quartz and feldspar, which are usually regarded as pressure effects, are found in such crushed dikes.

It is not uncommon to find the schists carrying numerous garnetiferous veins or dikes lying parallel to the foliation. Some consist of quartz and feldspar, others largely of quartz. They swell and pinch abruptly and range from half an inch to 12 inches in thickness. Garnets appear not only in the dikes but also in the wall rock in immediate contact with them, which in many places appears to have been schist not normally garnetiferous. On the southeast side of Eagle Glacier, where these features are well shown on the glaciated outcrops, the schists inclose numerous white fine-grained dikelets containing many small red garnets. Such dikes in thin section show a granulated aggregate of minerals, comprising orthoclase, plagioclase, quartz (which is strained), garnet, muscovite, myrmecitic intergrowths, and a small amount of pyrrhotite. Whatever igneous textures were once present have been obliterated by subsequent mashing.

From such rocks, which would doubtless be termed dikes, there is every gradation down to discontinuous plates a fraction of an inch thick intercalated between the foliation planes of schists. The appearance of these plates suggests that they are due largely to recrystallization of the sedimentary rock, with some addition of material from magmatic solutions flowing along the foliation planes. 
AGE.

The diorite invades the rocks of the Berners formation and is consequently post-Jurassic in age. The upper limit is indicated by the fact that on Admiralty Island Eocene conglomerates ${ }^{1}$ are found to contain pebbles of the diorite, showing that the intrusion took place in Cretaceous time. The general history of southeastern Alaska suggests that the diorite is of early rather than late Cretaceous age.

\section{MINOR INTRUSIONS AND DIKES.}

Minor bodies of intrusive rocks in considerable number and variety penetrate the slates and graywackes. With rare exceptions they lie parallel to the structure of the inclosing rocks. Many of them have been altered by dynamic metamorphism or by mineralization, or by both processes, and are generally referred to as greenstones according to local usage, but investigation shows that they include a wide range of rock types. Augite, commonly in idiomorphic crystals, is an abundant constituent of the rocks called diorite, gabbro, melaphyre, and lamprophyre in this report, and the presence of this mineral causes them to resemble one another, especially when the primary characters have been obscured by the later metamorphic processes. Although the distinction between the various augitic rocks is not always easy, it has been thought best to attempt it where possible rather than to cover their individuality under the blanket term "greenstone."

\section{ALBITE DIORITE.}

A number of dikes of unusual composition occur in the stretch of territory between Juneau and Auke Lake. In accordance with the usage of Spencer the rock of these dikes is designated albite diorite, by which is meant a granular igneous rock whose essential feldspar consists of a nearly pure albite. Spencer described in detail such rocks on Douglas Island, where they are of great economic importance because they constitute the ore-bearing rock at the Treadwell group of mines, but they have not previously been noted to occur on the mainland.

The dikes lie parallel to the stratification of the inclosing rocks and range from a few feet to 100 feet in thickness. They have been much altered by dynamo-metamorphism and by mineralization, so that it has been impossible to obtain entirely fresh material. This is particularly true of the thinner dikes, which are commonly gneissic or even schistose and are ramified by white veinlets in which albite is extremely abundant.

The most satisfactory material was obtained from the dike on which the Boston mine at Juneau is situated. This dike is 100 feet thick and shows a roughly gneissic structure from place to place. This 
rock is a medium-grained dark-colored diorite of even texture, composed, so far as determinable by the eye, of plagioclase feldspar and numerous fine flakes of biotite and chlorite, which give it a rather basic appearance. Under the microscope the dominant constituent is seen to consist of long tabular idiomorphic crystals of feldspar, which concordant optical tests, including the determination of the maximum refractive index as 1.54 in a liquid of known index, show to be a nearly pure albite of the composition $\mathrm{Ab}_{95} \mathrm{An}_{5}$. Orthoclase and microperthite are present in subordinate amounts as interstitial filling between the albite crystals. The biotite is mainly secondary and is apparently derived from hornblende. Apatite, which is unusually abundant, titanite, and magnetite comprise the accessory minerals. Secondary minerals are common and include chlorite, sericite, calcite, zoisite, and epidote.

This rock is in many respects similar to that of the Alaska-Treadwell mine, specimens of which were examined for comparison. Rock from the 330-foot level proves microscopically to consist largely of idiomorphic albites embedded in microperthite and orthoclase. The albite corresponds to $\mathrm{Ab}_{95} \mathrm{An}_{5}$; the core of the crystals is commonly altered to a mixture of zoisite and sericite. Hornblende of the ordinary brown-green variety is present in euhedral crystals, many of which, however, are partly or wholly pseudomorphosed by an intensely pleochroic biotite. Other minerals found in minor amounts are epidote, calcite, pyrite, titanite, apatite, and magnetite.

Some of the rock from the Boston mine, the freshest obtainable, was submitted to chemical analysis, the results of which are given in the following table. An analysis of Treadwell rock is added for comparison.

Analyses of albite diorite.

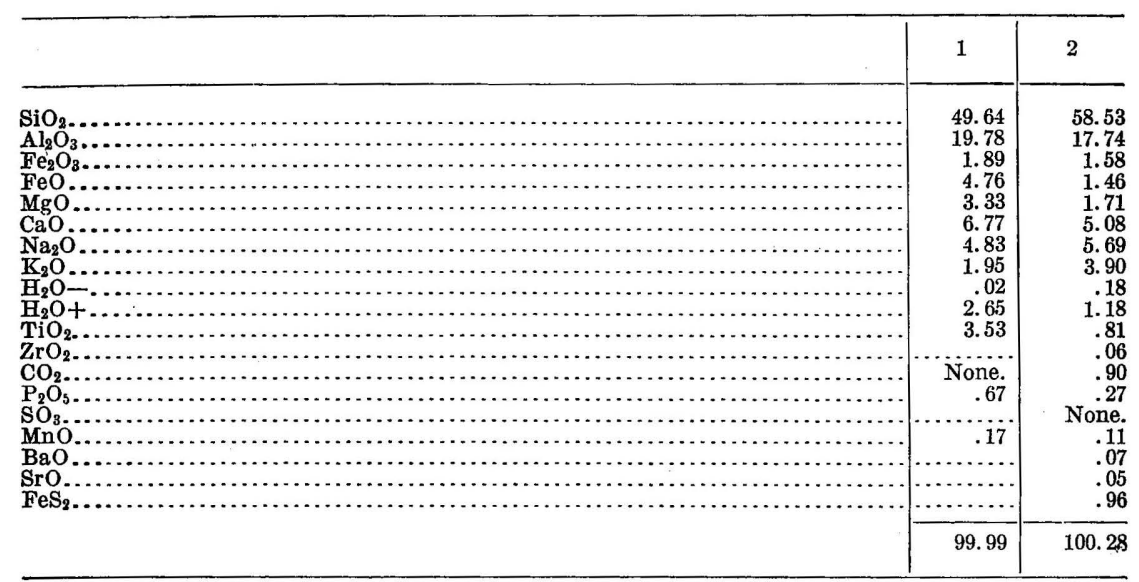

1. From Boston mine, Juneau. J. G: Fairchild, analyst.

2. From Treadwell mine, Douglas Island. George Steiger, analyst. Bull. U. S. Geol. Survey No. 287, 1906, p. 101 . 
The rock from the Boston mine is considerably lower in silica and much higher in titanic oxide than that from Treadwell. Two other analyses from Treadwell, both of much altered rock, are available, but show wider differences than the one cited. The analyzed material from Treadwell contained only a small amount of ferromagnesian minerals, ${ }^{1}$ so that it is believed that if analyses of the hornblende and titanite-rich albite diorite from the Ready Bullion mine were at hand they. would show a closer correspondence to the rock of the mainland.

\section{AUGITE DIORITE.}

A narrow belt of diorite 5 miles long extends south from Eagle River. This rock is of medium to fine grained texture and is composed essentially of plagioclase feldspar, augite, and biotite. The feldspars have been partly converted to epidote, and the dark minerals are somewhat altered to chlorite, so that the rock tends to assume a green hue. The diorite has exerted considerable metamorphism along its contact with the slates and has changed them to exceedingly dense hornstones in which all traces of original cleavage are obliterated. This action has extended 25 feet or more normal to the contact.

From its description it is apparent that the augite diorite differs considerably from the quartz diorite occurring along the northeast margin of the gold belt. It represents a separate intrusion, like the Jualin diorite at Berners Bay, but differs in composition from that rock also. There is no conclusive evidence available with regard to its age, but as it is unaffected by the gneissic structure of the quartz diorite it is probably a younger intrusion than the main mass of diorite of the Coast Range.

Under the microscope the diorite is found to be composed of tabular plagioclase, which is altered beyond specific determination, augite in abundance, biotite, sporadic hornblende, and orthoclase filling the triangular interstices between the plagioclase feldspars. Apatite and leucoxene are present as accessory minerals; epidote and chlorite occur as secondary products.

A prominent dike several hundred feet thick, which can be traced for a distance of 7 miles southeastward from Eagle River along the hills flanking the northeast side of Peterson Creek, appears to be related to the augite diorite. This dike consists of a dark-colored diorite containing numerous large tabular crystals of feldspar, which become especially conspicuous on weathered surfaces and impart to the dike a distinctive appearance that renders it different from all other dikes in the region. The dike lies parallel to the cleavage and stratification of the inclosing rocks; it dips $20^{\circ} \mathrm{N}$. on the southeast end, steepens gradually northwestward, and stands almost vertical 
at Eagle River. Where contacts can be observed, it is found that the marginal portion of the dike is strongly chilled and that the rock contains scattered crystals of tabular feldspar embedded in a dense matrix.

The normal porphyritic diorite of this dike, as seen under the microscope, consists of large tabular plagioclase feldspars, which are much altered, and a granular matrix consisting of plagioclase, augite, biotite, and interstitial orthoclase, together with. unusually abundant apatite. The femic minerals are considerably chloritized. The mineralogical composition is thus similar to that of the augite diorite and leads to the conclusion that the dike is only another form of the same magma. It is probable that a number of other diorite dikes, which have been much altered by vein-forming solutions and are commonly designated greenstones, belong to the same period of intrusion.

There are other dikes in the region which contain too much augite to be classed as diorites and are probably gabbros. An analysis of a uralitized dike showing their basic character is given on page 39 . They differ in appearance, color, and mineral composition from the amphibolite dikes in the schist belt, which were derived from gabbros of closely similar chemical composition.

\section{DIORITE PORPHYRY.}

A number of diorite porphyry dikes, ranging in thickness from 4 to 40 feet, are present in the region south of Eagle River. Some of them are particularly well exposed in the beds of streams which follow the courses of the dikes for several miles. The dikes conform in strike and dip with the inclosing rocks, and it is a common feature for the thicker dikes to be accompanied by one or more narrow dikes lying a few feet away in the hanging wall or footwall. The inclosing rocks are commonly slates, but on Spuhn Island and the peninsula on the east side of Auke Bay the dikes intrude pyroclastic beds.

It is a fact of some interest that the diorite porphyry dikes have a considerable distribution in the adjoining region to the south. They were noted by Spencer ${ }^{1}$ along the east side of Douglas Island, where the largest dike, on Lawson Creek, has a width of nearly 400 feet. They occur along the north shore of Douglas Island and are common along the west shore, and they occur on Admiralty Island along the shore of Stephens Passage. Some of the dikes cut across the folds of the inclosing rocks, and on the north shore of Douglas Island one of them was found to cut a dike of augite lamprophyre 75 feet thick.

The diorite porphyry dikes have a characteristic appearance and are not likely to be confused with any of the numerous greenstone dikes 
and sheets intercalated in the slates. They are rocks of white or light-gray color. A few are stained red near the surface from the oxidation of a small amount of finely disseminated pyrite. The porphyritic structure is due to the presence of white feldspar phenocrysts and slender prisms and needles of hornblende embedded in a finely granular or felsitic groundmass. On the peninsula on the east side of Auke Bay one of the dikes was noted to carry large corroded phenocrysts of quartz in addition to the other porphyritic constituents, but dikes of this kind are rare. Under the microscope the feldspar phenocrysts are found to range from andesine to oligoclase, the hornblende to be altered to chlorite and calcite, and the groundmass to consist of a microgranular aggregate of feldspar and quartz. Considerable alteration has taken place, as is shown by the ubiquity of calcite and sericite.

\section{LAMPROPHYRIC DIKES.}

Dikes of lamprophyric character are of widespread occurrence in the region. Two kinds have been recognized-one containing numerous porphyritic augite crystals embedded in a subordinate matrix of green color, a rock which will be designated an augite lamprophyre, and the other a black rock of a basaltic aspect that appears to correspond to that of the dikes which were called minettes by Spencer, ${ }^{1}$ but which were left without precise petrographic identification. The lamprophyric character of all these dikes is expressed by the recurrence of the ferromagnesian minerals in two generations, by the absence of feldspars from the porphyritic constituents, and by the subordinate position of the feldspars. The dikes are not known to be associated with any particular magma, nor do they appear in the vicinity of the great plutonic intrusions, as do the salic granitoids of the region.

The augite lamprophyre dikes are far more common than those of the basaltoid variety. They have been noted throughout the region from Berners Bay southward; also on the north shore of Douglas Island and on Admiralty Island along the shore of Stephens Passage. They range up to 100 feet in thickness and commonly lie parallel to the structure of the inclosing rocks, but some, like the 75-foot dike on the north shore of Douglas Island, break across the strata. In some of the dikes augite phenocrysts form the bulk of the rock. In the better-preserved examples the augite crystals have a fresh green vitreous appearance. A few of these dikes can not easily be distinguished from the highly porphyritic varieties of augite melaphyre. It is not impossible that the augite lamprophyres are the dike equivalents of the surface volcanic rocks, but the evidence at hand seems to make them belong to a later period of igneous activity. 
Under the microscope such a rock is found to consist largely of idiomorphic augites, many of which are surrounded by a fringing growth of tremolite fibers. Smaller crystals of augite and some intensely pleochroic brown hornblende are inclosed in the matrix, which consisted originally of an isotropic material now largely converted to tremolite. Entirely amphibolized dikes occur at Berners Bay. ${ }^{1}$

The lamprophyric dikes of basaltic appearance are not common. On the east side of Auke Bay is a particularly fine example 6 feet thick, trending diagonally across the slates. The rock is highly porphyritic, containing large, thick tables of biotite, some of which exceed 1 inch in diameter, and prisms of hornblende and augite. On the hanging wall there is a strongly marked chill selvage 5 inches wide; it shows flow banding and contains only numerous crystals of biotite in parallel orientation. A thin section cut from the central portion of the dike shows that the phenocrysts consist of hornblende, augite, and biotite; the biotite is strongly corroded and does not appear in the groundmass, which consists largely of slender hornblende prisms with sporadic augite, the interstices between these minerals being filled with striated feldspar of the composition of labradorite. Magnetite and apatite are abundant accessory minerals; calcite forms amygdular patches.

A few other thin dikes of the same general character are known. They are the equivalents of the intrusive rocks called minettes, which are found near Juneau. A lamprophyric dike cutting the greenstone and slate on the north side of Gold Creek, opposite the Last Chance placer, consists essentially of phenocrysts of tabular pyroxene, olivine, biotite, and hornblende named in the order of abundance, embraced in a matrix which is in part isotropic, in part zeolitic, and in part probably orthoclase. A few oval areas, doubtless amygdules, are filled with zeolites inclosing sporadic crystals of hornblende, biotite, and titanite. A clear isotropic mineral with index below that of the zeolite forms an interstitial filling between the zeolite prisms and is probably analcite. This rock appears to correspond with the rock from the Treadwell mine described by Becker ${ }^{2}$ and termed by him an analcite basalt.

\section{QUATERNARY DEPOSITS.}

The Quaternary deposits consist of silts and gravels of glacial, fluvial, and marine origin. A mantle of tough glacial till covers much of the bedrock of the region, reaching up to altitudes of 2,500 feet,

1 Knopf, Adolph, Geology and mineral resources of the Berners Bay region, Alaska: Bull. U. S. Geol. Survey No. 446, 1911, p. 18.

2 Eighteenth Ann. Rept. U. S. Geol. Survey, pt. 3, 1898, p. 59. 
although scattered ice-borne bowlders are found in some abundance as high as 3,400 feet. On the geologic map (Pl. II, in pocket) only the large gravel plains extending out from the fronts of the existing glaciers and the deposits along the principal streams are indicated by the Quaternary pattern.

Marine deposits were found at a number of localities and are believed to have a much wider distribution, although generally concealed under a cover of moss and vegetation. Below the lower canyon of Lemon Creek gravel banks 60 feet high are exposed, consisting of silts, well-rounded gravels, and clean sands in horizontal beds. A pebbly silt contains numerous marine shells in a fine state of preservation. The inland extension of this marine formation formed the bedrock on which rested the auriferous gravel of the lower part of Lemon Creek.

Near the mouth of Eagle River a highly fossiliferous beach deposit was found 30 feet above extreme high tide. It rests on glacially polished bedrock, is 10 feet thick, and is fossiliferous throughout. The material of which it is composed consists of well-rounded and subangular pebbles of various rocks; some also are angular, and of these some were coated with barnacles over an inch long. The matrix in which the pebbles are embedded is a blue sandy clay, of rather solid consistence. Marine gravels were found also at an altitude of 100 feet on the summit of the divide through which the Amalga tramway passes after leaving the flats of Eagle River.

The fossils were submitted to W. H. Dall, who reports on them as follows:

They are similar to those of the bowlder clay series of Douglas Island reported on by me in the reports of the Harriman Alaska Expedition (vol. 4, 1904, p. 121). They comprise the following species, all but two of which are found living in the vicinity of Juneau:

5459. Lot 1, Lemon Creek. Cardium decoratum Grewingk (extinct), Leda fossa Baird. 5460. Lot 2, Eagle River. 100 feet above sea. Mya truncata L., Saxicava arctica L., Cardium ciliatum Fabr., Maconı sabulosa Spengler.

5461. Lot 3, Eagle River. 40 feet above sea. Chrysodomus liratus Martyn, Pecten islandicus Muller, Cardium ciliatum Fabr., Venericardia gouldii Dall, Macoma sabulosa Spengler, Astarte near borealis Schum., Mya truncata L., Balanus sp.

The marine shells found by Dall on Douglas Island occur at 200 feet above sea level. The observations that have been made indicate that northward along Lynn Canal the emergence of the region from beneath the sea in postglacial time was only 100 feet, but they are not sufficiently extensive to be conclusive.

The marine occupation left no obvious topographic marks of its presence, and is therefore easily overlooked.

$17883^{\circ}-$ Bull. $502-12-3$ 


\section{ECONOMIC GEOLOGY.}

\section{GENERAI STATEMENT.}

Gold lodes constitute the only mineral resource of this region at present under development. The ore bodies are mainly in the form of stringer lodes; a few occur as fissure veins and a number consist of mineralized dikes. Although the different varieties of ore bodies are essentially of the same age and origin, this threefold classification brings together deposits characterized by features that are important both practically and theoretically.

Nearly all the ore bodies occur within the belt of slates and graywackes; a few are found in the quartz diorite gneiss and in the volcanic rocks; but although a large amount of quartz veining is present in the schists, no ore bodies of economic importance are known to occur in the schist belt. The distribution of the deposits, including those of the Juneau and Berners Bay regions, with reference to the geologic formations is shown on Plate V.

The portion of the slate belt adjoining the schists appears from the present state of development of the region to be a particularly favorable zone of mineralization. This zone corresponds to what Spencer ${ }^{1}$ has termed the "main lode system" of the Juneau region, where it is highly productive at Silverbow Basin. The ore bodies in the region north of Juneau are, however, not restricted to this zone, and some of the largest and most promising prospects have been found a long distance within the footwall of the main lode system.

The outcrops of ore bodies lying below timber line are as a rule concealed under several feet of stiff glacial drift, and this overburden is itself covered by a heavy growth of moss and vegetation. It is not unusual to find that trees have grown on the tops of the lodes, and a number of ore bodies have been discovered by finding quartz fragments in the roots of overturned trees. The continuity of quartz outcrops beneath the overburden is usually determined by "sounding," which is done by prodding an 8-foot double-pointed steel rod through the covering of moss and drift and listening to the sound of the blow it makes. Trenching and open cutting are guided by such preliminary examination.

The development and exploitation of the ore bodies of the region are facilitated by the strong relief, which favors the use of tunnels to obtain depth on the lodes. At present none of the ore bodies have been undercut deeper than 200 feet below the outcrop, and as a whole the development of the region is not far advanced.

\section{STRINGER LODES.}

The ore bodies designated stringer lodes are belts of slaty or schistose rock cut by irregular and discontinuous quartz stringers. As a rule the ore bodies tend to follow the structure of the inclosing 


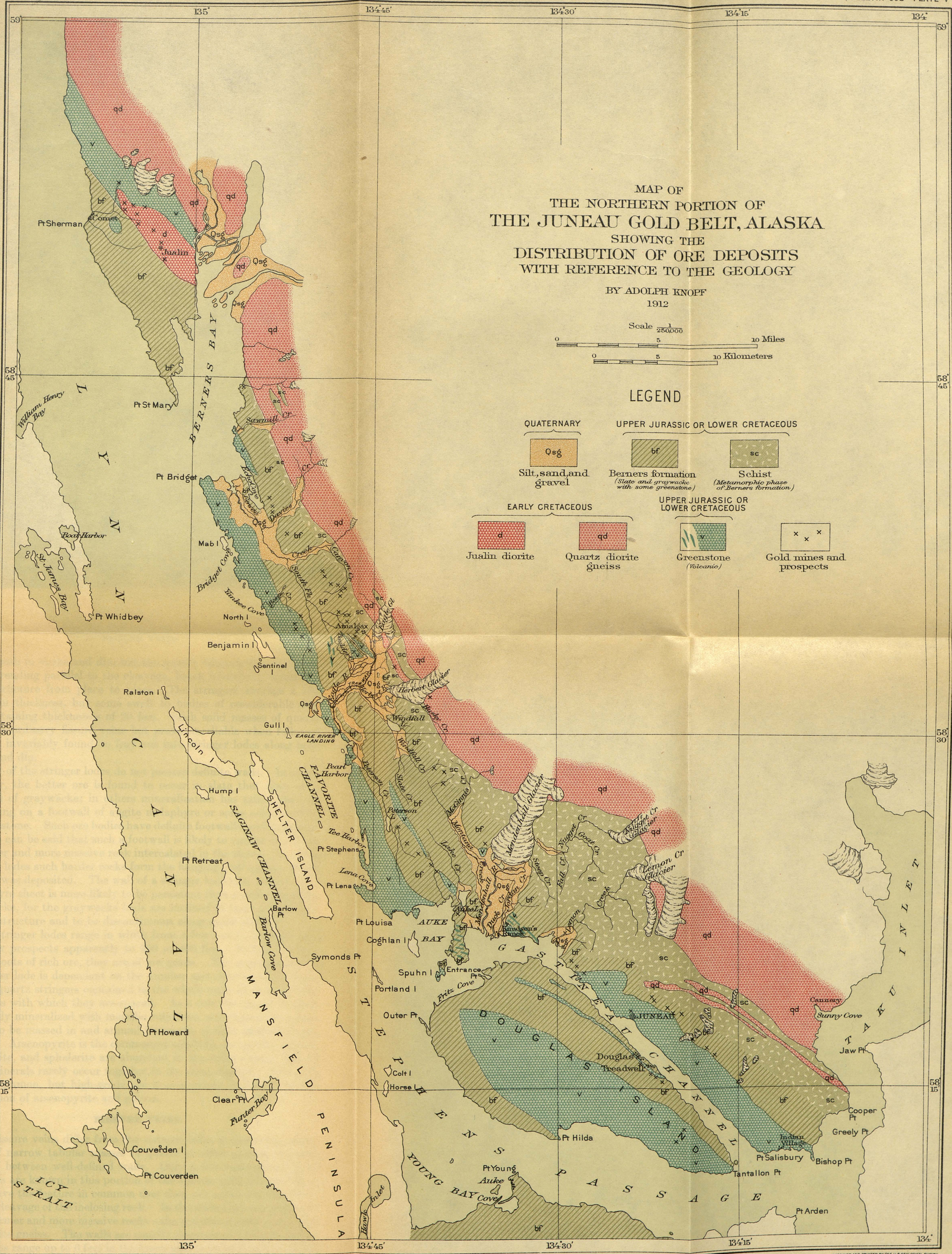



rocks, both in strike and dip, but the quartz veinlets, although generally trending parallel to the cleavage, break irregularly across the slaty structure from place to place. The stringers average a few inches in thickness, but some swell to bodies of considerable size, even attaining thicknesses of 20 feet. Such solid masses of quartz resemble ordinary fissure veins but prove unreliable when followed and are invariably found to fray out into stringer lodes along both strike and dip.

Many of the stringer lodes do not possess definite walls. In some, however, the better ore is found to occur in slate that rests on a footwall of graywacke; in others mineralization has taken place in slate lying on a footwall of augite melaphyre or some other variety of greenstone. Such ore bodies have definite footwalls, and in general terms it can be said that such a footwall is likely to consist of a sheet of harder and more massive rock intercalated in the slates. In a few stringer lodes such harder rocks form the hanging wall against which the ore was deposited. The wall of a stringer lode that consists of a melaphyre sheet is more likely to be persistent than a wall formed by graywacke, for the graywacke beds are inclined to have a short lenticular structure and to be discontinuous along strike and dip.

The stringer lodes range in width from a few feet to 100 feet, and at a few prospects apparently to 300 or 400 feet. Except for sporadic shoots of rich ore, they are of low grade. The average value of a stringer lode is dependent on the number and richness of the individual quartz stringers contained in the whole mass of slate and the closeness with which they are spaced. As a rule the quartz veinlets are leanly mineralized with metallic sulphides, and these have a tendency to be massed in and around fragments of slate inclosed in the quartz. Arsenopyrite is the commonest sulphide, and pyrite, galena, pyrrhotite, and sphalerite are abundant in the order named, but all these minerals rarely occur together in the same deposit. Free gold is not common, but high-grade ore is everywhere indicated by the association of arsenopyrite and galena.

\section{FISSURE VEINS.}

The fissure veins differ from the stringer lodes in consisting essentially of narrow tabular masses of quartz or other gangue material inclosed between well-defined walls. Only a few representatives of this class are known in this portion of the Juneau gold belt and all of them have the feature in common that they cut across the stratification or cleavage of the inclosing rock. In the main they are restricted to the firmer and more massive rocks - the volcanic conglomerate and the diorite gneiss. The walls are usually determined by fault planes. The veins range up to 6 feet in thickness and carry gold up to a value of $\$ 12$ a ton. 


\section{MINERAITZED DIKES.}

The mineralized dikes are few in number and, with one exception, have attracted little attention in recent years. They include two petrographic types-gabbro and albite diorite. The dikes are cut by stringers, the larger of which consist of coarse white quartz and the smaller-those under an inch in thickness-of quartz, albite, and dolomite. Many of the thinner veinlets consist entirely of albite. The rock included between the network of veinlets has undergone a powerful alteration and is impregnated with metallic sulphidespyrrhotite, pyrite, and arsenopyrite. In spite of the chemical dissimilarity of the two kinds of dike rocks, the alteration in some respects is strikingly similar and the albite diorite and gabbro are both saturated, as it were, with albite. The profound transformation that some of these dikes have experienced makes the determination of their original character a matter of doubt.

The altered albite diorite dikes show certain features peculiar to themselves. The unaltered rock is dark colored, but where mineralized it has been changed to a white rock, which is cut by numerous veinlets consisting of quartz, albite, dolomite, and related carbonates, commonly somewhat iron bearing. The principal sulphide is pyrite; arsenopyrite, pyrrhotite, galena, and sphalerite are present in minor amounts. The presence of rutile is characteristic, commonly in sagenitic aggregates of brilliant adamantine prisms. The smaller veinlets penetrating the mineralized dike rock consist largely of albite, and where the veinlets are drusy this mineral is crystallized in typical feldspar forms.

This highly.interesting kind of mineralization is essentially similar to that which has affected the Treadwell dikes, which lie a few miles south of this region, but it by no means follows that mineralization of this character was everywhere accompanied by the formation of gold deposits of commercial value. Nevertheless it is a favorable feature, and in view of the fact that such dikes contain enormously valuable ore bodies on Douglas Island, efforts should be made to prospect thoroughly the albite diorite dikes of the mainland.

The ores of the mineralized dikes are of low grade, running at most a few dollars to the ton. Assays, not of rich stringers, but of samples taken across the whole width of an ore body, appear rarely to have been made, so that authentic data with regard to the tenor of these ores are not available.

\section{METASOMATIC PROCESSES.}

The slates inclosing ore bodies show little evidence of metasomatic changes, but the igneous rocks affected by mineral-bearing solutions show obvious marks of profound alteration. The most common change is that due to a large introduction of albite in the altered rock, 
which is in places so pronounced as to be apparent to the unaided eye. Especially is this true where the dikes are ramified with small veinlets, which, as already stated, in general consist mainly of albite. Other changes of less common occurrence are the conversion of hornblende or other amphiboles into biotite and the introduction of apatite into the altered wall rocks.

Albitization is a form of thermal hydrometamorphism characteristic of the Juneau gold belt and appears to have been independent of the original amount of soda in the altered wall rocks. It has taken place in albite diorite, where it might be interpreted as a mass reaction, but has also occurred with nearly equal facility in normal diorite, gabbro, and amphibolite. To throw light on the character of this alteration, chemical analyses of rocks from widely separated localities in the gold belt have been made.

The conversion of hornblende into biotite is not a common form of metamorphism accompanying the introduction of gold ores, but its occurrence in a few localities has been described-at Rossland, British Columbia ${ }^{1}$ in the important Kolar gold district in India: ${ }^{2}$ and at Juneau. ${ }^{3}$

The introduction of apatite was first suggested by the fact that extraordinarily long and slender needles of this mineral were found traversing a succession of contiguous mineral grains, in places as many as six separate grains. As the grains were derived by crushing and granulation from preexisting minerals, it was not easily conceivable how the long needles of apatite could have escaped breaking and faulting, such as is commonly seen in dynamically deformed igneous rocks. Further, it was discovered that the abundance of apatite appeared to increase with the amount of alteration that the rock had undergone, and this correspondence recurred too often to be a fortuitous coincidence. In places apatite forms a plexus of needles, in which the individual needles range down to ultramicroscopic dimensions. Rarely was it found in the minute veinlets traversing the metasomatically altered rocks. The marked tendency of apatite to form needles penetrating the other constituents makes it analogous to tourmaline in its metasomatic development.

Analyses of altered and unaltered rock from the northwest side of Mendenhall Glacier have been made to establish the nature of the chemical changes. The relatively unaltered rock-that is, unaltered by mineralization-consists of dark olive-green rock of fine texture inclosing numerous black euhedral crystals of augite, which impart to it a porphyritic appearance. Under the microscope, however, the augite phenocrysts prove to consist of actinolitic amphibole,

\footnotetext{
1 Lindgren, Waldemar, Metasomatic processes in fissure veins: Trans. Am. Inst. Min. Eng., vol. 30, 1901, p. 609

2 Hatch, F. H., Mem. Geol. Survey India, vol. 33, pt. 1, 1901, p. 7; also Rept. Dept. Mines, Mysore, 1899.

3 Spencer, A. C., Bull. U. S. Geol. Survey No. 287, 1906, p. 63.
} 
and amphibole forms the dominant constituent of the rock. Zoisite and epidote are abundant, granular albite forms an interstitial material, and biotite occurs in small amount. Scattered spots of white earthy material appear to represent altered titaniferous magnetite. Apatite is a rare accessory. The rock is accordingly a massive amphibolite derived, as the chemical analysis shows, from a type of gabbroic composition. In the quantitative classification it is a camptonose near auvergnose. It is possibly the dynamically metamorphosed equivalent of the rocks called augite lamprophyre in this report.

The amphibolite, where mineralized, is traversed by an irregular network of thin auriferous veinlets, which are composed of albite and calcite and carry some pyrrhotite and in places black mica. The amphibolite between the veinlets has been altered to an even-grained, finely granular black rock slightly impregnated with pyrrhotite. Microscopically it is found to be composed largely of biotite of an intensely pleochroic variety in fine flakes and tufted or fan-shaped forms. Albite and zoisite comprise the remaining important constituents; chlorite, calcite, and pyrrhotite occur rarely. Apatite in all sections examined showed a perceptible increase over that in the unaltered amphibolite. The enrichment in apatite was particularly noticeable in a section cut from rock inclosed between closely spaced albite veinlets and consisting essentially of albite.

From the chemical and microscopic data the following approximate computations were made:

Mineral composition of fresh and unaltered amphibolite.

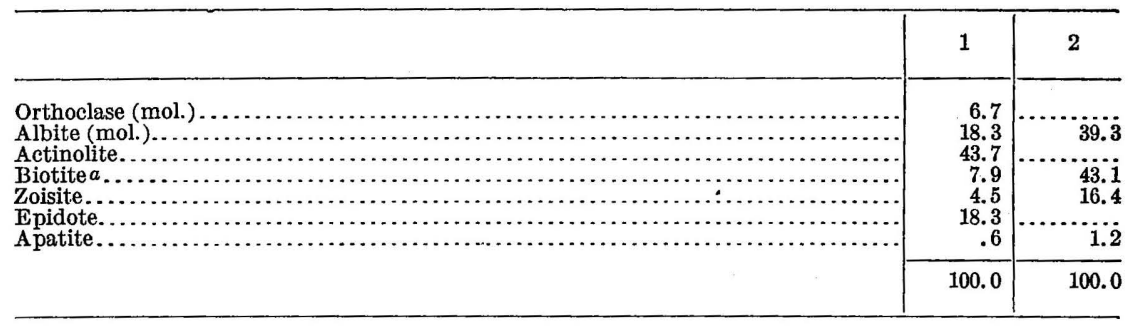

$a$ By difference.

1. Relatively unaltered amphibolite.

2. Altered amphibolite.

On the assumption that the volume remained constant during the progress of metasomatic alteration, calculations have been made to show the gain and loss of each constituent in terms of the original mass. ${ }^{1}$ The results are given in column 4 of the subjoined table. They confirm the deductions drawn from the microscopic analysis; they show a large addition of soda and potash, as demanded by the

${ }^{1}$ Lindgren, Waldemar, Trans. Am. Inst. Min. Eng., vol. 30, 1901, p. 591. Ransome, F. L., Prof. Paper U. S. Geol. Survey No. 66, 1909, pp. 180-181. 
formation of albite and biotite, and heavy losses in magnesia, lime, and iron, especially in ferric iron. Of interest is the fact that combined water exhibits a decided loss. Phosphoric pentoxide shows a substantial addition, and although a slight change in the amount would make a large percentage increase because of the small quantities involved, yet the addition is sufficiently large to carry conviction that phosphoric pentoxide has actually been introduced.

Chemical alteration of amphibolite.

\begin{tabular}{|c|c|c|c|c|c|c|}
\hline v & 1 & 2 & $1 \mathrm{a}$ & $2 a$ & 3 & 4 \\
\hline 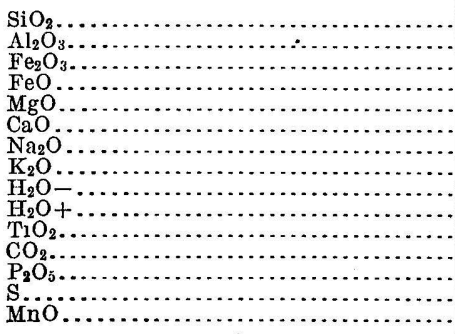 & $\begin{array}{r}48.30 \\
13.59 \\
3.12 \\
10.44 \\
6.29 \\
11.09 \\
2.16 \\
1.55 \\
.00 \\
2.06 \\
1.01 \\
\text { None. } \\
.26 \\
\text { None. } \\
.25\end{array}$ & $\begin{array}{r}52.92 \\
20.53 \\
\text { Trace. } \\
8.38 \\
2.43 \\
4.76 \\
4.67 \\
2.96 \\
.18 \\
1.58 \\
.99 \\
.57 \\
.28\end{array}$ & $\begin{array}{c}148.9 \\
41.9 \\
9.64 \\
32.2 \\
19.4 \\
33.8 \\
6.68 \\
4.78 \\
.00 \\
6.35 \\
3.12 \\
.80 \\
.77\end{array}$ & $\begin{array}{c}154.0 \\
59.6 \\
.0 \\
24.4 \\
7.07 \\
13.8 \\
13.6 \\
8.61 \\
.52 \\
4.60 \\
2.88 \\
1.66 \\
. .61\end{array}$ & $\begin{array}{l}+5.1 \\
+17.7 \\
+9.64 \\
-7.8 \\
-12.33 \\
-20.0 \\
+6.92 \\
+3.83 \\
\pm .34 \\
-2.25 \\
-\quad .24 \\
+\ldots .86 \\
+\ldots .04\end{array}$ & 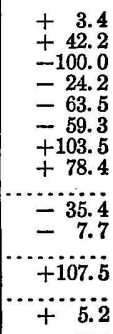 \\
\hline & 100.12 & 100.25 & 1308.34 & 1291.55 & -16.8 & n.... \\
\hline
\end{tabular}

1 The analyses have not been recast to 100 per cent and all computations were made with the slide rule. The errors thus introduced are outside the limit of accuracy as shown by the summations of columns 1a and $2 a$, which should be respectively 308.4 and 290.5 .

1. Chemical analysis of unaltered amphibolite. J. G. Fairchild, analyst. Specific gravity of rock

specimen 3.084 . Chemical analysis of altered amphibolite. J. G. Fairchild, analyst. Specific gravity of rock speci-
. men 2.005 .

1a. Constituents, in grams, in 100 cubic centimeters of unaltered amphibolite.

2a. Constituents, in grams, in 100 cubic centimeters of altered amphibolite.

3. Gains and losses in grams in the alteration of 100 cubic centimeters of amphibolite to same volume of altered product.

4. Gains and losses of each constituent in terms of its own mass in the unaltered amphibolite.

The albite diorite, whose analysis is given on page 28 , is partly altered, as shown by the prevalence of secondary biotite -and other commoner secondary minerals, such as epidote, zoisite, chlorite, sericite, and carbonate. The abundant accessory apatite is possibly in part secondary. The most highly altered phase consists of a mixture of carbonate, albite, and sericite, with accessory apatite and titaniferous magnetite, partly converted to a white earthy material. The veinlets under an inch in thickness that traverse such altered rock consist of albite and dolomite. The metasomatic changes are entirely similar to those worked out in detail by Spencer ${ }^{1}$ for the Treadwell ore bodies.

At the Crystal mine at Port Snettisham, 30 miles southeast of Juneau, the ore body consists of a quartz fissure vein, averaging 4 feet in thickness, inclosed in a country rock of schistose zoisite amphibolite. The appearance of the amphibolite suggests that it has been derived from a porphyritic basalt in which the original 
feldspar phenocrysts have been saussuritized and drawn out. In thin section the rock proves to be composed largely of amphibole, zoisite, and epidote, with subordinate albite, which is closely associated with the epidote minerals. The amphibole comprises two varieties, a brown-green, strongly pleochroic variety, and a lightgreen, feebly pleochroic variety. Other constituents are ilmenite, titanite, chlorite, and muscovite. The chemical analysis of a specimen of this rock obtained near the entrance to the upper tunnel of the mine is as follows:

Analysis of amphibolite from Port Snettisham.

[J. G. Fairchild, analyst.]

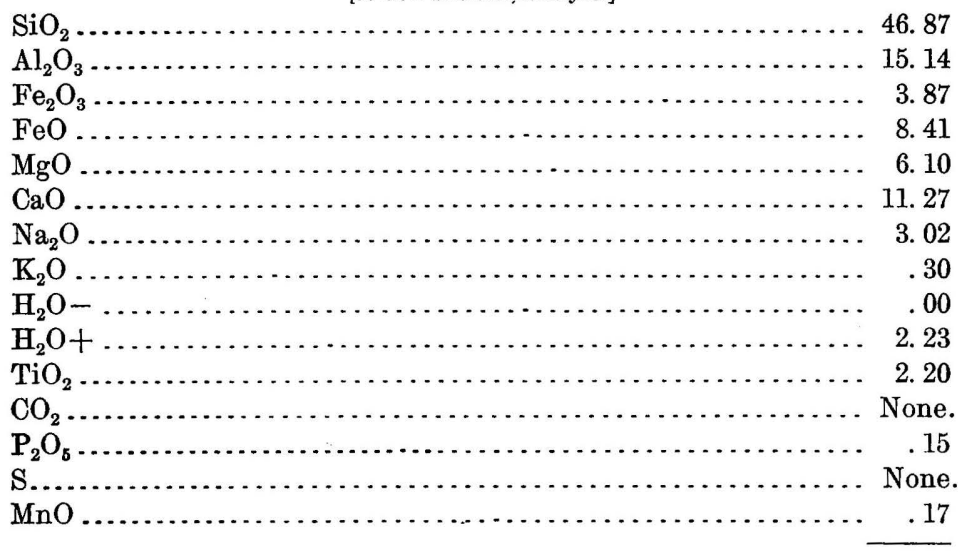

99.73

The unaltered amphibolite is a dark, nearly black rock; that near the vein is a light-gray, nearly white rock studded with cubes of pyrite, so that it is apparent even to the unaided eye that a profound alteration of the amphibolite has taken place. Under the microscope the altered rock is found to be composed mainly of albite, with minor amounts of quartz, pyrite, carbonate, chlorite, and accessory apatite. The albite, which is in part twinned according to the Carlsbad and albite laws, is generally anhedral, except where in contact with quartz or carbonate, where it is idiomorphic. During alteration, therefore, the amphibolite was transformed into practically an albite rock.

The foregoing discussion of the metasomatic processes tends to show that albitization is a common mode of alteration in the Juneau gold belt and was determined not by the composition of the wall rocks but by the composition of the vein-forming solutions. These solutions were rich in soda and potash, and the chemical work done by them shows that they were hot, ascending waters of deep-seated origin. They carried phosphoric acid and were able to cause the formation of apatite in the altered wall rocks, which allies these 
solutions to those active during stanniferous mineralization. Concurring testimony is found in the fact that the solutions were able to transform hornblende into biotite, a reaction which takes place, as shown by Barrell, ${ }^{1}$ under hydrothermal conditions at temperatures slightly lower than those closer to the igneous contact.

\section{ORIGIN OF THE ORE DEPOSITS.}

The problem of the origin of the mineralization of the Eagle River region is a part of the problem of the origin of the ore deposits of the Juneau gold belt. This problem has been discussed in detail by Spencer on the basis of a careful study of the extensively developed mines in the vicinity of Juneau, and he came to the conclusion that the vein-forming waters were in general of magmatic origin. ${ }^{2}$ The evidence of the northern part of the belt is entirely in conformity with this hypothesis and, it is believed, adds strength to it.

The distribution of the gold deposits-the fact that they are practically absent from the quartz diorite; that, although present in the schists, they are not auriferous in paying quantity; and that they are restricted to the slate belt-might easily lead to the suggestion that while the lodes were being formed the quartz diorite and schist were still too highly heated to allow the precipitation of the gold, and that consequently the auriferous solutions were forced to flow out into a cooler environment before depositing their metallic burden. This explanation, however, may not be adequate, for in the Berners Bay region, which forms the northwestern extremity of the gold belt, the ore bodies are situated mainly in the Jualin diorite, an intrusive mass of igneous rock younger than the great body of quartz diorite which forms the hanging wall of the gold belt. On the other hand, the facts stated may be taken to indicate that the ore deposits at Berners Bay are slightly younger than those of the rest of the Juneau gold belt and that auriferous deposition in this belt continued during a long period of time.

The lodes are believed to have been formed prior to the Eocene epoch, from the fact that in Silverbow Basin the quartz veins are cut by basaltic and diabasic dikes, which are regarded as equivalent to the surface basalts of Eocene age found in many parts of southeastern Alaska.

The profound nature of the chemical changes that the vein-forming solutions were able to effect in the wall rocks of the ore bodies, as shown on preceding pages, indicates that the deposits were formed by rising thermal waters. The solutions were acting under conditions

\footnotetext{
1 Barrell, Joseph, Geology of the Marysville mining district, Montana: Prof. Paper U. S. Geol. Survey No. 57,1907 , p. 140 .

Bull. U. S. Geol. Survey No. 287, 1906, pp. 30-32.
} 
approaching those that exist during contact metamorphism; they were able to convert hornblende into biotite, to introduce apatite into the wall rocks, and to cause the abundant formation of albite. Among the minerals contained in the veins pyrrhotite and biotite are of genetic significance, being characteristic, according to Lindgren, ${ }^{1}$ of the deeper vein zones. The collective evidence thus establishes the conclusion that the ore bodies are in all probability of deepseated origin.

The fact that the solutions acted under conditions approaching those of contact metamorphism, taken in connection with their sequence upon the diorite invasion, strongly suggests that they were eruptive after-effects of the intrusion of the diorite magma. They were therefore of the nature of attenuated pegmatite solutions, highly siliceous but carrying considerable dissolved soda feldspar, a mineral common in igneous rocks, pegmatites, and certain auriferous quartz veins.

As part of the larger problem-the origin of the mineralization of southeastern Alaska - the argument in support of the magmatic derivation of the vein-forming waters is greatly strengthened by the striking relation shown in the distribution of the mineral deposits. They are found to be clustered along the intrusive contacts of granitoid rocks of Mesozoic age, not only along the western border of the Coast Range batholiths and around the margins of the satellitic bosses scattered throughout the Alexander Archipelago, but also along the eastern border of the diorite core of the Coast Range from Portland Canal northward to White Horse.

It may be regarded as proved that the copper ores of the Ketchikan district were produced as a result of the intrusion of granitoid rocks. ${ }^{2}$ They are contact-metamorphic bodies of auriferous chalcopyrite in a gangue of calcite and lime silicates, principally the lime-iron garnet andradite. The proof is clear and convincing that here the gold was directly derived from a magmatic source. The gold content rises with the percentage of copper, and, although small, in some of these ores it exceeds that of the ores worked solely for their gold content in the Juneau region.

The glacial erosion to which the ore deposits were subjected in the recent geologic past has exposed at the surface the primary sulphides, which have been oxidized to an unimportant extent in postglacial time. In view, then, of the proved similarity of the mineralization of the Eagle River region to that of ore deposits near Juneau, whose favorable behavior in depth has been demonstrated by extensive mining operations-the stringer lodes to a depth of 900

1 Lindgren, Waldemar, Econ. Geology, vol. 2, 1907, p. 123.

2 Wright, F. E. and C. W., Bull. U. S. Geol. Survey No. 347, 1908, p. 83. 
feet, the mineralized dikes to 1,800 feet-the probabilities strongly favor the assumption that in this region the gold content found near the surface will persist downward without essential change of value.

\section{PRACTICAI CONCLUSIONS.}

Some inferences of a practical character have already been pointed out, especially as applying to further exploration of the mineralized dikes. A most striking fact in the geology of the region is the almost complete restriction of the ore bodies to the belt of slates and graywackes. Although the ore bodies have been found throughout the length and breadth of the area underlain by those rocks, they are nevertheless most numerous in the zone lying along the belt of schists. Moreover, the highest-grade ore yet found in the region and the only productive mine occur in that zone. The conclusion is therefore plain that those portions of the belt adjoining the schists that have not been adequately prospected are favorable fields for further investigation, notably the stretch between Windfall Basin and Eagle River and possibly that between Mendenhall Glacier and Montana Basin. Much prospecting has been done, and the easily discovered deposits were long ago found; but, as recent discoveries suggest, doubtless many others remain hidden under the overburden of moss and till.

In other parts of the slate-graywacke area the contacts with the intercalated masses of augite melaphyre, breccias, and conglomerates (rocks that are collectively known in the region as greenstone) appear to form favorable localities for mineralization. The masses of harder rock are likely to betray their presence, at least in parts of the region, by forming the bedrock of knobs or other topographic prominences.

A few small fissure veins have been found that break across the structure of the quartz diorite gneiss. The entire length of some of these veins is absolutely exposed on the bare glaciated surfaces and does not reach 200 feet; the width is a few inches. Although some of these veins contain considerable free gold, they nevertheless show a surprising lack of alteration of their wall rocks, such as generally accompanies productive ore deposits. In view of this unfavorable feature and the shortness and narrowness of the veins, extensive sinking of shafts on them is a waste of time and energy. Where larger and longer ore bodies are indicated and the diorite is intensely altered by the action of vein-forming/solutions, as on the flank of Mount Thane, further prospecting is to be encouraged.

The future of the district will, however, depend largely on the exploitation of the low-grade stringer lodes. The history of the mineral development of Silverbow Basin, at Juneau, will probably be repeated here. In early days attempts were made to mine some of the stronger veins found in the stringer zones of slate in Silverbow 
Basin, but owing to the discontinuous character of these veins the mines founded on such attempts were destined to a precarious existence. By a natural evolution, which is still going on, methods have slowly and gradually been developed to mine and mill the whole mass of rock of the ore-bearing zone, and the practice has now settled down to exploiting ores ranging from $\$ 1.25$ to $\$ 3$ a ton in value. This is likely to be the course of development in the northern extension of the Juneau gold belt.

\section{DESCRIPTIONS OF INDIVIDUAL PROPERTIES.}

The properties are described in geographic order, from Berners Bay southeastward to Salmon Creek, except that the only operating mine is described first. By no means all the prospects are described; most of the claims that have been located in the region cover stringer lodes, and these are essentially similar from one end of the belt to the other. The descriptions here given are restricted to those prospects on which considerable work has been done or which illustrate the characteristic geologic features of the occurrence of the gold ores. The amount of space devoted to any prospect, however, is no measure of its economic value.

\section{EAGLE RIVER MINE.}

The Eagle River mine is situated at the head of Eagle River, 7 miles inland from Lynn Canal. It is connected by a horse tramway of easy grade with tidewater at Eagle Cove, where wharfage can be procured by any of the vessels plying the waters of southeastern Alaska. The mill, whose elevation is only 200 feet above sea level, has 20 stamps and is operated by water power. A few houses and a general store are situated near the mill, and the Government has established here a post office which is officially known as Amalga.

The Eagle River lode was discovered in October, 1902, by two prospectors, Messrs. Sandstone and Neil Ward. The discovery was the result of systematic prospecting, for rich float of a characteristic appearance had been found in a gulch near by, but the actual finding of the outcrop of the lode was hastened by chance. One of the prospectors, while returning to camp late in the evening through the dense woods, saw quartz entangled in the roots of an overturned tree, and on examination discovered the outcrop of the sought-for lode. The property was sold in May, 1903, for $\$ 150,000$, and energetic development was immediately commenced; before the close of the year the mill, the surface and aerial tramways, and a road had been built.

The mine is developed by tunnels; the main haulage tunnel, known as level No. 1, is situated 800 feet above the mill and is connected with 
it by a wire tramway. Approximately 30,000 feet of drifts and tunnels had been driven at the time of writing.

The rocks at the mine consist of an interstratified series of clay slates and graywacke slates, with which are associated a few thin intrusive sheets of green augite melaphyre. A few other types are found, but they are exceedingly rare. Near the end of the 200-foot crosscut into the footwall on level No. 1 a 3 -foot bed of light-colored siliceous schist was encountered, which simulates an aphanitic flowbanded rhyolite with small porphyritic crystals. Such rocks that differ greatly from the associated beds may perhaps be of service when attempts are made to relocate ore bodies lost through faulting. This is particularly true of the melaphyre sheet occurring in the footwall of the lode, which may be reasonably expected to possess both regularity and continuity. For example, the melaphyre in the 200foot footwall crosscut on level No. 1 probably corresponds to the similar rock exposed along the flume line 300 feet south of the aerial tramway and indicates the position of the lode line, which is here covered with slide material.

The rocks, where undisturbed, trend between $\mathrm{N} .30^{\circ} \mathrm{W}$. and $\mathrm{N}$. $45^{\circ} \mathrm{W}$. (true meridian) and dip from $60^{\circ} \mathrm{NE}$. to $90^{\circ}$, ranging near $70^{\circ}$. Owing to gravity creep because of the very steep slopes, they generally lie flat or even with reversed dip. In some of the gulches the horizontal slates can be seen partly resting on vertical slates, the zone of crushed slate that separates the slates in normal position from those that have slumped over being well shown. Underground operations show that this creep and landslide action is far more extensive and persists deeper than would be suspected from the surface exposures. Broad zones of broken and ground-up slate were encountered in the mine and when wet formed a running mass of clayey mud. This gave much trouble, necessitating heavy timbering, and in some places it was found impossible to keep the drifts open and hundreds of feet of workings have had to be abandoned. It is reported that in some tunnels 100 feet or more underground logs and diorite bowlders were encountered, proving that the landslide action took place in postglacial time. This action has broken the continuity of the ore deposit, and as landslides act under the force of gravity, masses of ore torn off from the roots of the deposit in place will have moved out into the hanging wall, because the hanging wall is on the downslope side of the mountain. The writer believes, however, that beyond this general tendency to be displaced to the hanging-wall side, nothing can be postulated as to the probable position of the displaced masses of ore. It is likely that their orientation in both strike and dip will be radically changed.

Level No. 1 undercuts the original Eagle outcrop at a depth of 215 feet, and the ore has been stoped out from this level to the surface. 
The workings extend more than 1,000 feet northwestward along the trend of the ore zone, but sinking has not been attempted from this level. The ore body in the outcrop was 250 feet long and, as described by Wright, ${ }^{1}$ consisted of a chain of three ore shoots, elliptical in cross section, striking N. $30^{\circ} \mathrm{W}$., dipping $50^{\circ} \mathrm{NE}$., and pitching northwestward into the mountain at an angle of $30^{\circ}$. They averaged from 5 to 15 feet in width. At the time of the writer's visit the old workings were no longer accessible. The different shoots are stated to have carried distinctive ores. High gold values were generally accompanied by large quantities of metallic sulphides; quartz heavily mineralized with arsenopyrite and galena was especially good ore. In spite of its base character the ore is reported to have been 90 per cent free milling; the arsenopyrite-galena concentrates carried $\$ 100$ a ton in gold. In places a honeycombed quartz barren of sulphides carried considerable free gold.

Much broken ground was encountered in following the ore zone northwestward. The ore extracted during 1909 and 1910 belonged to the stringer-lode type, with some lenticular masses of quartz. There is a certain tendency for good ore to localize along the contacts of thick graywacke beds with black slate. Commonly the slate resting on the graywacke is intensely crushed and ribboned with quartz. But this is not an invariable rule, for one of the largest lenses of quartz, having maximum dimensions of 100 feet in length, 20 feet in width, and 30 feet in height, possessed no definite walls. The central portion consisted of massive quartz, but toward the periphery the ore body frayed out into irregular veinlets penetrating the surrounding highly polished carbonaceous or graphitic slate. The major axes of the quartz mass corresponded in direction with the strike and dip of the slate. Some of the quartz contained much silvery-white mica; the sulphides, mainly arsenopyrite, were sparse in amount, but the slate was in places highly impregnated with barren arsenopyrite. Toward the center of the quartz body considerable quartz was encountered carrying massive pyrrhotite with some galena scattered through it, and this constituted ore of good grade.

\section{CALIFORNIA PROSPECT.}

The California group of claims is situated 1 mile by trail southeast of the head of Echo Cove, at an altitude of 600 feet. This group, which was located in 1897 by J. G. Davies and E. P. Pond, of Juneau, consists of three claims trending northwest. Above this is the Gold Standard group of three claims, which was located in 1896 and subsequently purchased from the original locators.

The country rock consists of black clay slates, green schists, augite melaphyre (greenstone), and breccia, and is exposed near the mouth 
of the stream on which the workings are situated. The strike is N. $30^{\circ} \mathrm{W}$. and the dip $60^{\circ} \mathrm{NE}$. The ore bodies follow the contacts of the more massive augite melaphyre and the slaty rocks.

The main tunnel (at the blacksmith shop) is 160 feet long and forlows the foliation of the green schists lying against a hanging wall of augite melaphyre. This is a heavy rock, somewhat sheared, especially along the margins. It is of dark dull-green color and is characterized by the presence of numerous porphyritic crystals of augite. The ore body consists of a belt of glossy green schist irregularly traversed by veinlets composed of quartz, calcite, and ferruginous carbonate. Arsenopyrite, with which in places is associated a small amount of galena, is common, both in the veinlets and in the schist. The average thickness of the lode is 3 feet.

A few hundred feet to the northwest some tunneling has been done on another lode exposed at the bottom of a 15-foot fall in the stream. The tunnel follows the contact between slate and augite melaphyre, which forms the footwall of the lode. The maximum veining has taken place in the crushed slate lying immediately against the greenstone footwall.

On the Gold Standard group a tunnel 120 feet long follows a stringer lode in green slate along a footwall of augite melaphyre. The thickness of the ore body ranges from 2 to 6 feet. Arsenopyrite is the principal sulphide and is commonly concentrated in the pieces of slate inclosed in the quartz; galena occurs rarely. According to $\mathrm{Mr}$. J. R. Whipple, sampling across a width of $4 \frac{1}{2}$ feet averaged $\$ 6$ a ton in gold.

\section{AURORA BOREALIS PROSPECT.}

The Aurora Borealis group, commonly known as the A. B., is situated $2 \frac{1}{2}$ miles from Yankee Cove, a small indentation 6 miles northwest of the mouth of Eagle River. A partly dismantled 5-stamp mill stands on the property; it was operated for a short time prior to 1895 and is said to have produced $\$ 5,500$ in gold. The mill is connected with the beach by a 12 -foot planked roadway.

The principal workings accessible at the time of visit in 1910 were two tunnels situated a short distance behind the mill. Both slightly exceed 200 feet in length and both follow the vein, the upper tunnel being 85 feet above the lower. The average strike of the vein, as determined from the course of the lower tunnel, is N. $40^{\circ} \mathrm{E}$.; the average dip is $27^{\circ} \mathrm{NW}$. The vein ranges in thickness up to $3 \frac{1}{2}$ feet of solid quartz and in places splits up to a stringer lode. A ribbon structure parallel to the walls is well shown. The sulphides in the ore are arsenopyrite, pyrite, and subordinate galena. The country rock inclosing the vein is black clay slate, which is somewhat unusual in that it contains numerous large ellipsoidal concretions, some resembling a football in size and shape. The greenstones-that is, the 
augite melaphyres and their associated clastic rocks, which here include a great volume of firmly lithified conglomerate-form the mountain lying between Kowee Creek and Yankee Cove, and the contact between them and the slates is encountered in the upper tunnel.

\section{BESSIE PROSPECT.}

The Bessie vein is situated $2 \frac{1}{2}$ miles from Yankee Cove. The developments consist of two tunnels and a shaft. The depth attainable by these workings can not exceed 100 feet. The main tunnel is situated at an altitude of 1,700 feet, or 700 feet above the Aurora mill, and is 240 feet long. In this tunnel, which follows the ore body and strikes $\mathrm{S}$. $75^{\circ} \mathrm{W}$., the vein averages $1 \frac{1}{2}$ feet in thickness and stands practically vertical. A sheeted structure is a marked feature of the vein and the quartz has a brecciated appearance. At 110 feet from the portal the vein is faulted a short distance northwest along a fault zone trending $\mathrm{N} .15^{\circ} \mathrm{W}$.; one wall of the fault is a curved surface showing horizontal flutings. The vein was recovered by deflecting the tunnel to the northwest.

At a distance of about 1,200 feet along the prolongation of the vein southwestward a crosscut tunnel 125 feet long was driven intersecting the bottom of the shaft, and the vein was explored by a drift 75 feet long.

The rocks inclosing the vein are mainly greenstone conglomerates containing well-rounded pebbles up to 5 inches in diameter, but they are so thoroughly indurated that they break across the pebbles rather than around them. The strike of the conglomerate is $\mathrm{N} .30^{\circ}$ W., so that the vein, which strikes $\mathrm{N}$. $75^{\circ} \mathrm{E}$., cuts almost at right angles across the trend of the formation. At the mouth of the crosscut tunnel graywacke and slate are exposed.

The vein ranges from a foot to 5 feet in width and averages between $1 \frac{1}{2}$ and 3 feet. The quartz carries small amounts of pyrite and arsenopyrite and rare galena and sphalerite.

\section{ALASKA-WASHINGTON PROPERTY.}

The Alaska-Washington vein lies half a mile southeast of the Bessie property. The developments consist of four drift tunnels, aggregating 500 feet, a 70 -foot raise, and a 30-foot shaft. The shaft is the uppermost working and is at an altitude of 1,600 feet, 800 feet higher than the lowermost tunnel and 2,000 feet distant from it horizontally along the strike of the vein.

The vein trends N. $85^{\circ} \mathrm{E}$., is vertical, and crosscuts the same greenstone conglomerates that inclose the Bessie vein. The walls are well defined. The vein averages 3 feet in thickness, but expands in places to 6 feet. Locally the fissure is largely filled with country rock or reticulated with stringers. The ledge has been affected by 
considerable internal movement, and the stringers are crushed and faulted. The quartz shows large, powerfully slickensided surfaces and extensive brecciation and is more or less stained by iron oxide and locally by black manganiferous films. The ore on the lower tunnels is heavily charged with coarsely crystalline pyrite, with which a small amount of sphalerite is associated. Where the pyrite is thoroughly oxidized, considerable fine gold is visible. The gold, so far as present developments show, is limited to short shoots. Possibly the vein has suffered local impoverishment near the outcrop, due to the action of manganiferous chlorine-bearing solutions. To test this possibility and to determine the character of the vein below the zone of oxidation, it would seem advisable to concentrate all future development work on the lowermost tunnels, where, because of the increase of depth that can be rapidly attained, the workings would soon pass beneath the oxidized ore.

This property has long lain idle, but work was resumed in a small way in 1910. One mile to the southeast are a number of claims under the same ownership, known as the Mother Lode group. Open cuts at intervals along a length of several thousand feet expose considerable masses of quartz lying in greenstone conglomerate near its contact with the belt of slates to the northeast. Where the bodies of quartz exhibit any particular trend they cut across the formation. As a rule the quartz is devoid of pyritic mineralization, but arsenopyrite and pyrite are found in the altered conglomerate wall rock.

YANKEE BASIN PROSPECTS.

The amphitheater-like depression at the head of Cowee Creek is called Yankee Basin. Of the numerous prospects situated in this basin the one on which the largest amount of work has been done is the Dividend lode. A 1,200-foot tunnel diagonally crossing the formation intersects the lode at 1,000 feet from its mouth and at a depth of 187 feet. The

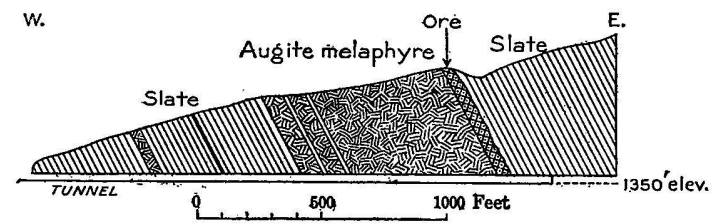

FIGURE 1.-Diagrammatic section along Dividend tunnel. geologic features along the line of this tunnel are shown in the accompanying diagram (fig. 1). The thick belt of augite melaphyre was evidently a controlling factor in determining the location of the zone of mineralization. The upper 300 feet is solid igneous rock, but the lower 100 feet, as indicated diagrammatically in the sketch, consists of an alternation of slate and melaphyre. The augite melaphyre is considerably shattered and sheared, especially on the footwall of the lode, where it has suffered considerable further alteration as a result of the action of vein-forming solutions. Where $17883^{\circ}-$ Bull. $502-12-4$ 
comparatively unsheared, the melaphyre is a green rock containing numerous porphyritic crystals of augite, but many of these are reduced to green glossy patches of chlorite.

The lode rests on the melaphyre as a footwall and consists of a belt of black, highly polished graphitic slate traversed by thin stringers of quartz carrying some calcite. Pyrite is the most common sulphide and is confined mainly to the slate inclosing the veinlets; arsenopyrite, galena, and free gold are occasionally tound. A drift tunnel turned off from the crosscut tunnel follows southeastward along the footwall of the lode (or hanging wall of the greenstone) for a distance of approximately 200 feet. The lode is also exposed for a few hundred feet along the strike in the bed of the stream above the tunnel, where it is 12 feet wide. At 235 feet above the portal of the tunnel there is a short crosscut, with a shaft, now flooded with water.

The Cascade lode is situated at an altitude of 2,000 feet. The principal work done here consists of an inclined shaft dipping $50^{\circ} \mathrm{NE}$. and steepening to $70^{\circ}$ at a depth of 50 feet; the total depth is reported to be 90 feet. The ore body forms a 6 -foot stringer lode in black clay slate and bluish graywacke slate. In places the graywacke slate is acutely crinkled. The metallic minerals in the quartz stringers include considerable arsenopyrite, with minor amounts of galena and sphalerite. The ore is said to average $\$ 12$ over a width of 5 feet.

There are a large number of other lodes situated around the upper portion of Yankee Basin and extending northwestward to the headwaters of Canyon Creek, but not much exploration work has been done on them. All belong to the class of stringer lodes, although they contain in places solid bodies of quartz of considerable width. Of the lodes may be mentioned the Julia No. 1, 12 feet wide; the Julia No. 2, 8 feet wide; the Puzzler, 14 feet wide; and the Noonday, 6 feet wide.

\section{CANYON CREEK PROSPECTS.}

The bedrock at the head of Canyon Creek consists of slates-both black clay slates and graywacke slates--striking N. $50^{\circ} \mathrm{W}$. (true) and dipping $70^{\circ} \mathrm{NE}$. The graywackes show a remarkably curly structure. On exposed surfaces they are of light-gray color, owing to the bleaching of the carbonaceous matter and the whitening of the component feldspar grains. On the northeast the slates grade into phyllites, which become progressively more crystalline toward the quartz diorite gneiss contact. An overburden of glacial clay filled with diorite bowlders mantles all bedrock, even on slopes as steep as $30^{\circ}$. This has been stripped and sluiced off at many places and a considerable number of stringer lodes have been uncovered outcropping on the glaciated surfaces.

The most work has been done on the E Pluribus Unum claim, on which, at the time of visit in 1909, a tunnel 250 feet in length and 
raises aggregating 80 feet had been driven. In the surface outcrop the stringer lode is 8 feet thick but is only part of a mineralized zone 35 feet or more in width; against the hanging wall, which is a bed of graywacke, is a solid vein of quartz, 20 inches wide, well mineralized with arsenopyrite, galena, and sphalerite. A number of independent assays have shown that this part of the ore body averages between $\$ 200$ and $\$ 300$ a ton in gold. The length of this rich shoot is 18 feet. The tunnel was driven in the endeavor to undercut the shoot at a depth of 127 feet, but this endeavor was not successful, and a raise was put up, which is reported to have encountered the ore.

The Black Chief lode, situated near the E Pluribus Unum, is well exposed in a stream which flows along it for a distance of 75 feet. A tunnel approximately 180 feet long undercuts the lode. The slates near the entrance are very regularly stratified, trending $\mathrm{N}$. $55^{\circ} \mathrm{W}$. and dipping $80^{\circ} \mathrm{N}$., but in the ore zone they are thoroughly smashed, the ore consisting of black, shiny slate reticulated with narrow quartz stringers. The quartz carries a small quantity of sulphides, consisting of pyrite and galena. The width of the lode is rather indefinite and ranges from 4 to 20 feet.

Across the divide northwest from Canyon Creek are the Yankee Boy prospect, usually known as the Joyce-Jensen property, the Maud S., and the Blue Jay prospects, all quartz slate stringer lodes of the same general character. The Yankee Boy outcrop is situated at an altitude of 2,450 feet. A tunnel 40 feet long is drifted on the lode at this point. The lode is 12 feet wide, 8 feet of which is said to run $\$ 7$ a ton and the remainder between $\$ 1$ and $\$ 2$. Another tunnel, of which 100 feet was completed, has been started somewhat below the older tunnel to undercut the ore body.

\section{OLESON PROSPECT.}

The Oleson prospect is situated in the canyon of a small stream entering Eagle River from the northwest a mile or more below Amalga. The stream flows along a narrow belt of slate that is intercalated between two thick belts of volcanic rocks. These include some highly amygdaloidal augite melaphyres, but consist largely of the breccias that are commonly associated with those rocks. It is found that these volcanic rocks thin out rapidly toward the northwest and interlayer with slates, so that their representation on the geologic map is somewhat diagrammatic.

The prospect, which is exposed by two open cuts and a short tunnel, lies along the contact of the clay slate band and the volcanic belt to the south, in what are apparently transitional rocks. Some narrow quartz veins, doubtless part of a stringer lode, trending N. $30^{\circ} \mathrm{W}$. and dipping $60^{\circ} \mathrm{N}$., are exposed lying parallel to the structure. 
Arsenopyrite is the only sulphide and is commonly found as sharp, brilliant crystals embedded in the rock fragments inclosed in the quartz.

\section{ST. LOUIS AND SUMOMIT CLAIMS.}

The St. Louis claim is situated on the east side of Herbert Glacier, half a mile above the mouth of Husky Creek. Owing to the comparatively recent recession of the ice, the country rock bordering the glacier is well exposed on extensive polished surfaces. It consists of quartz diorite gneiss of the usual appearance and mineral composition. At the locality at which some work has been done a shear zone, bounded by well-defined walls and 7 feet wide, is exposed trending N. $20^{\circ} \mathrm{E}$. and dipping $60^{\circ} \mathrm{E}$. To the northeast it passes beneath the glacier; to the southwest beneath morainal débris. About 40 feet of ore is shown along the strike and ranges up to 4 feet in thickness; it is reported to average $\$ 5$ a ton in gold. The ore is a breccia composed of quartz fragments in a matrix of altered dioritic material. Veinlets of coarse white quartz carrying arsenopyrite were crushed and subsequently recemented by a dense greenish material. The microscope shows that this cement consists of quartz, calcite, chlorite, sericite, albite, arsenopyrite, and a few anhedral grains of apatite. Pyrite and galena are rare. The wall rock has been considerably altered by the vein-forming solutions, and this action has extended about 6 inches from the lode. The rock retains its gneissic structure, but the feldspar augen have lost their characteristic vitreous freshness and have changed to soft dull masses; the hornblende and biotite have altered to dull-green chlorite. The microscope enables the changes to be followed in more detail. The plagioclase feldspar is found to be largely changed to calcite and sericite and in places to chlorite, the dark minerals have altered to chlorite, quartz remains unchanged, and a small amount of pyrite has been introduced.

The St. Louis claim is situated at an altitude of 800 feet; to the northeast, at 1,250 feet, is the Summit claim. A vertical ledge, 6 to 8 inches wide, is exposed here, trending N. $60^{\circ} \mathrm{E}$. or transverse to the gneissic structure in the quartz diorite country rock. As shown on the glaciated surfaces, all the rock being bare, the total length of the ledge is 150 feet. The quartz is well mineralized with arsenopyrite and free gold is not uncommon. A shaft 30 feet deep has been sunk. The ore is rather oxidized, and the oxidation is said to extend to the bottom of the shaft. The wall rock of the vein shows no alteration, the biotite of fragments of wall rock inclosed in the vein having remained brilliantly lustrous. This lack of alteration is somewhat surprising when contrasted with the marked changes produced in the wall rock of the St. Louis prospect near by.

These prospects, with that of Mitchell \& McPherson, are among the very few that occur in the diorite gneiss-the so-called granite hanging wall of the Juneau gold belt. 
MITCHELI \& MCPHERSON PROSPECT.

The Mitchell \& McPherson prospect is situated on the northwest flank of the ridge between Eagle and Herbert glaciers. It was discovered in 1904, and since then a small amount of development work has been accomplished. A number of open cuts expose the lode extending up the steep mountain slope from an altitude of 1,300 feet to 1,600 feet. They are so situated as to be subject to the destructive action of rock slides, and to obviate this danger a tunnel 75 feet long was driven from a protected position but failed to reach the main ore body. In 1910 a new tunnel, which is planned to undercut the lode 100 feet vertically below the lowest outcrop, was commenced at a point secure from avalanches, and 35 feet of it, trending east, was completed.

The country rock inclosing the lode is a black diorite gneiss, which forms a band about 1,500 feet wide. The foliated structure of the gneiss, which is well marked, trends N. $40^{\circ} \mathrm{W}$. and dips $60^{\circ} \mathrm{NE}$. The footwall of this band of diorite gneiss is a belt of schists, which comprises a considerable variety of rocks. That immediately adjoining the gneiss is a garnetiferous biotite schist. The foliation of the schists is parallel to that of the gneiss.

The lode consists of a zone of crushed and mineralized diorite gneiss striking $\mathrm{N} .45^{\circ} \mathrm{E}$, nearly transverse to the foliation. The dip is probably vertical. The ore body, as exposed in the open cuts, averages 6 feet in thickness and is reported to average from $\$ 5$ to $\$ 12$ a ton in value. The surface ore is considerably stained by iron oxide, but the unweathered material is snow white. Sulphides are rare and consist of pyrite and galena. In a few places veinlets of quartz interlace the ore irregularly. The lowest outcrop of the lode lies in the diorite gneiss near the contact with the schists; whether the lode extends into the schist has not been determined.

The ore, when examined microscopically, is found to be composed of dolomite, albite, sericite, and accessory apatite. Minute veinlets of carbonate traverse the older dolomite and albite and indicate a second period of mineralization. The microscopic examination thus confirms the conclusion reached from the appearance of the ore-that intense changes were produced in the diorite gneiss by the solutions which brought in the gold.

\section{PETERSON PROPERTY.}

The Peterson property embraces 11 claims located end to end along a mineralized zone flanking the hills on the northeast side of Peterson Creek; side claims and mill sites bring the number of claims up to 18 or 20. The original locations were made by John G. Peterson in 1897 , and development proceeded in a small way until 1910, when a systematic and comprehensive attempt was made by the Alaska 
Consolidated Mines Co. to prospect the property. A 4-mile planked horse tramway was built from Pearl Harbor to the camp on the Prairie claim, a 500-foot crosscut tunnel was started, and a diamond drill was acquired, with which it was proposed to put down six 500foot holes to determine the continuity and value of the ore body in depth.

The main work has been done on the Prairie claim. The geologic features are shown on the accompanying diagram (fig. 2), which is drawn across the strike of the rocks. The prevailing country rock is a clay slate dipping at a low angle to the northeast. Four distinct kinds of greenstone are present in the vicinity. A dike of chloritized diorite lies in the footwall of the lode. The base of this dike is well exposed and shows that the dike was injected parallel to the stratification of the inclosing slates; the top is not exposed, but some contact-altered slate, impregnated with extremely fine pyrrhotite and pyrite, is found. The dike is estimated to be 80 to 100 feet thick. It outcrops intermittently for a mile toward the northwest. In its footwall there is exposed some augite lamprophyre-a rock

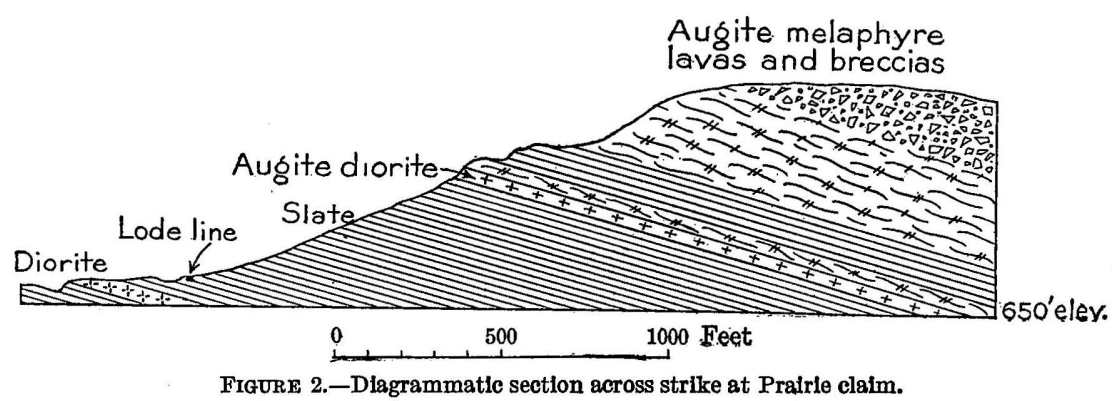

consisting of augite phenocrysts in a green, finely granuiar matrixbut because of the few outcrops not much is known concerning it. On the middle slope of the ridge to the northeast is a dike of darkcolored augite diorite carrying large, prominent tabular feldsparsa rock that has been described in detail on page 29 . The breccias and lavas of the augite melaphyre series form the summit of the ridge.

On the Prairie claim large masses of quartz, in places up to 30 feet in surface width, have been exposed over a length of 350 feet, with a general trend of N. $30^{\circ} \mathrm{W}$. As shown in one of the tunnels, which is driven under the overburden of glacial drift, some of the masses of quartz form flat bodies of irregular shape, from which stringers penetrate the surrounding slate, crosscutting the stratification. Ársenopyrite is the only sulphide in the ore; occasionally free gold is detected. Fragments and filaments of slate are embedded in the quartz, and the arsenopyrite is commonly localized in and around them. Several hundred tons of ore has accumulated on the dumps and is said to average $\$ 6$ a ton. 
MONTANA BASIN PROSPECTS.

On the head of Montana Creek, at altitudes of about 2,500 feet, a considerable number of stringer lodes have been discovered in the footwall zone of the schist belt. They embrace some of the oldest lode locations in the district, having been made as early as 1882. They have been difficult of access, but the recent construction of the Government road up the main valley of Montana Creek has ameliorated this difficulty.

At Patton claim a quartz vein trending obliquely across the strike of the country rock is exposed along a series of open cuts for several hundred feet. The inclosing rocks are thinly stratified fine-grained biotite schists; they strike N. $40^{\circ} \mathrm{W}$. and dip $50^{\circ} \mathrm{NE}$. The vein, which rests against a well-defined hanging wall, strikes N. $86^{\circ} \mathrm{E}$. and stands nearly vertical, thus cutting the formation at a considerable angle. In this respect the vein is nearly unique in the district. The ore body is narrow, ranging in width from a few inches to 2 feet. The quartz is stained by iron oxide and shows no sulphides but carries fine colors of free gold.

The mineralized zone exposed in Montana Basin extends northwestward into Windfall Basin. On the Smith \& Heid property two tunnels, aggregating 500 feet in length, have been driven to prospect a body of highly arsenical quartz ore exposed on the surface at an altitude of 2,000 feet. This ore was formerly roasted and treated in an arrastre. A few hundred feet to the northwest of this prospect a drift tunnel has been run 30 feet on a stringer lode several feet wide. The quartz carries considerable crystalltzed arsenopyrite and some galena, which, as a rule, is intimately intergrown with the arsenopyrite. Such ore is rather characteristic of this portion of the gold belt and here, as elsewhere, carries good values in gold. The country rock is a crinkled or curly black graywacke schist, somewhat impregnated with pyrite cubes and arsenopyrite crystals. In the creek below the tunnel bedrock is well exposed, consisting of interstratified clay slate and graywacke schist striking N. $35^{\circ} \mathrm{W}$. and dipping $70^{\circ} \mathrm{NE}$. Somewhat above this tunnel, upstream, is an outcrop of silvery-white fine-grained quartz sericite schist ribboned with narrow quartz stringers. In places it is highly mineralized, carrying finely granular galena, sphalerite, and pyrite, with which are also a little arsenopyrite and chalcopyrite. Red oxidized portions are said to pan gold. The belt of mineralized schist is at least 30 feet wide but has not been investigated carefully.

TREASURY HILL CLAIMS.

A group of 8 or 10 claims, usually known as the Wiley \& Spaulding property, is situated between 2 and 3 miles northwest of Auke Bay. The original discoveries were made in 1908, and their 
promising character led to a strong revival of interest in this portion of the Juneau gold belt.

The work done on the property consists of trenching the overburden of moss and till and a short tunnel, most of which was accomplished in 1909. Owing to negotiations pertaining to the sale of the property, no important work was undertaken during 1910.

Prospecting has been in progress at two places about 2,500 feet apart along the strike of the country rock. (See fig. 3.) At the

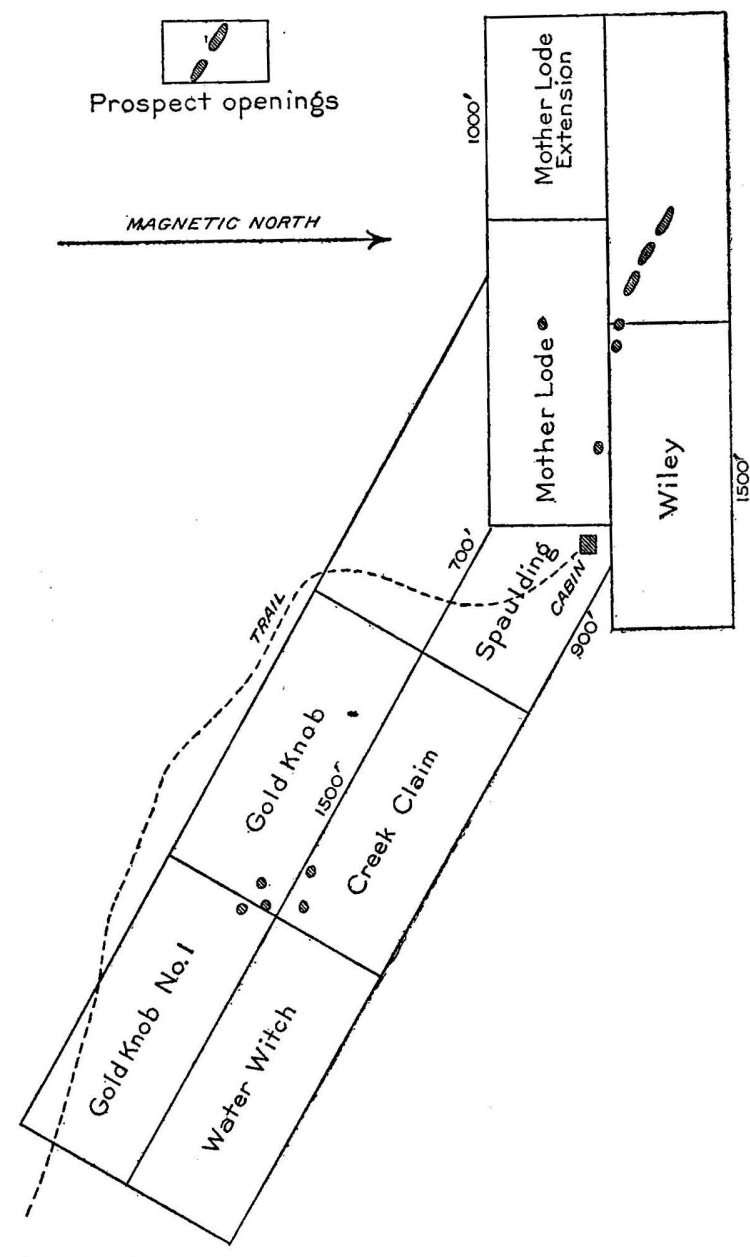

FrguRE 3.-Claim map of Treasury Hill group. upper locality, at an altitude of 1,550 feet, which the owners have named Treasury Hill, the country is open and parklike, in pleasant contrast to the dense thickets of young hemlock and the network of fallen timber that on $\checkmark$ cumber the lower locality. Natural rock exposures are rare, so that the geologic. interpretation must: be obtained mainly from the strippings and open cuts. Prospecting $h a s$ been most energetically carried on at the upper locality along a glacial sheepback, where, for a distance of over 500 feet along the strike, a series of prospect trenches exposes an ore body 50 feet or more in width. Stripping shows glaciated bedrock in all places.

The ore body consists of a grayish-green dike cut by quartz veins, generally trending transverse to the course of the dike and ranging up to several feet in thickness. The quartz is white and of coarse texture and in places is heavily charged with coarsely crystalline 
arsenopyrite. The dike rock is also interlaced with smaller veinlets, of which those under an inch in thickness are composed mainly of calcite and albite. Near the veinlets the rock is considerably impregnated with sharply crystalline arsenopyrite and irregular grains of pyrrhotite.

Green schists dipping northeastward at a moderate angle form the hanging wall of the dike, but the contact is obscured by oxidation, and it is not improbable that the green schist may represent the sheared margin of the dike. Black slates form the principal country rock in the hanging wall, striking N. $65^{\circ} \mathrm{W}$. (magnetic) and dipping $40^{\circ} \mathrm{N}$. A diorite porphyry dike is exposed in the creek a few hundred feet to the northeast. The width of the ore-bearing dike is not well shown, but is probably between 100 and 150 feet. The footwall consists of clay slate underlain by greenstones.

Microscopic examination of the dike rock shows that it has been so completely altered by the solutions that brought in the gold that its original character is no longer determinable. It is found to consist essentially of a fine-grained aggregate of albite, with subordinate amounts of chlorite, carbonate, sericite, arsenopyrite, and pyrrhotite and a relative abundance of apatite needles. However, at 1,500 feet southeast from the ore body along the strike there is an outcrop of a dike of heavy dull-green rock showing numerous porphyritic crystals of a black mineral suggesting augite. This rock is very probably the comparatively unaltered equivalent of the ore-bearing dike. Under the microscope it proves to contain much augite, which is now largely converted to actinolite and chlorite, with epidote and calcite and finely granular plagioclase. It therefore corresponds, as its appearance suggests, to the gabbro whose analysis is given on page 39.

The open cuts generally follow the transverse quartz veins that intersect the dike at right angles to its general course. As these veins carry the main values in gold, it is practically impossible to obtain an average sample of the ore body as a whole. Samples of apparently barren vein material-that is, rock from which all pieces showing mineralization were rejected-gave assays ranging for the quartz from a trace to $\$ 3$ a ton, the average being $\$ 1.35$. The altered diko rock averaged $\$ 1.10 .^{1}$ These are probably minimum values.

The other locality at which prospecting has been undertaken is situated at an altitude of 1,200 feet and is 2,500 feet southeast of the upper openings. Trenches here expose glaciated bedrock and show an enormous amount of quartz mineralization extending 400 feet along the strike and 200 to 300 feet or more across the strike. In places quartz forms solid exposures 50 feet across, though some of

1 Figures obtained from Mr. L. D. Huntoon. 
these bodies of quartz may represent transverse veins. Exploration is not sufficiently advanced to prove or disprove this possibility. In the interior of the mineralized zone there is a considerable amount of black slate interstratified with green feldspathic schist, which is associated with the quartz. The quartz is white, coarse, and of drusy or vuggy texture. It carries coarse gold. The metallic minerals are practically negligible in quantity; arsenopyrite and pyrite were the only sulphides observed. They are more common in the small stringers that cut the green schists and as impregnations in the green schists. Black glassy limonite occurs in places as an oxidation product. Veinlets of albite also are found in the schists, and the coarse white vein quartz that incloses fragments of schist contains numerous crystals of albite in clusters and isolated individuals, forming aureoles around the schist fragments.

\section{DULL \& STEPHENS PROSPECT.}

The Dull \& Stephens prospect, which was discovered in June, 1908, is situated 1 mile northwest of the head of Auke Bay. The deposit is mostly covered by 4 to 8 feet of tough, sticky till, which has been ingeniously sluiced off at several places by booming. Bedrock is exposed in this way along six open cuts, the longest 120 feet in length. The deposit in its maximum dimensions measures 120 by 200 feet and consists of irregular masses of quartz and bedrock. It lies near the contact of clay slates and augite melaphyre breccias; the slates are much shattered and dislocated, but where apparently undisturbed they trend N. $20^{\circ} \mathrm{W}$. and $\operatorname{dip} 60^{\circ} \mathrm{N}$. The main body of quartz is in the beds of volcanic breccia immediately beneath the slates. On glaciated bedrock exposed by stripping, the augite melaphyres show light-green surfaces much pitted by the etching out of the numerous augite crystals. One of the open cuts shows a tough massive greenstone, probably a dike in the breccias, which, as revealed by the microscope, is composed of calcite and chlorite, so that its original character is undeterminable. The only other kind of rock present is a narrow dike of diorite porphyry exposed at the head of the main open cut. This, like all other rocks in the vicinity, is much altered by mineralizing agents; the surface rock is soft, red, and rotten, but the unoxidized rock is nearly white and is sparingly impregnated with minute cubes of pyrite.

The quartz of the deposit is a white, coarse variety and contains practically no metallic sulphides. Arsenopyrite is extremely rare, and pyrite occurs to some extent in the country rock adjoining the quartz. The arsenical portion of the deposit yields the highest assay returns. During the sluicing of the outcrop several ounces of coarse rusty gold was obtained. 
WINN PROSPECT.

The Winn prospect is one of the oldest lode discoveries in the district and was located in 1882, the same year in which the discoveries at Montana Basin were made. The main development is a tunnel 20 feet long, situated at an altitude of 200 feet near the south end of Auke Lake. The geologic features are poorly exposed here on account of the dense growth of hemlock thicket and the deep covering of surface material.

The ore consists of dike rock irregularly cut by veinlets of quartz, albite, and ferriferous carbonate. In the vicinity of these stringers the rock is much impregnated with cubical pyrite and arsenopyrite and contains much albite and carbonate, which on weathering imparts a strong red color to the ore. The most unaltered-looking rock is found under the microscope to consist of carbonate, albite, chlorite, muscovite, pyrite, and accessory apatite which is fairly abundant in characteristic jointed prisms. On account of the great abundance of albite in the veinlets and dike as a whole, it is believed that the dike originally consisted of albite diorite, like that on Salmon Creek and at the Boston mine, Juneau.

The extension of this dike apparently outcrops at the outlet of Auke Lake, about 2,000 feet northwest of the tunnel. It is soft, rotten, and ocherous. The exposure here shows that green augite melaphyres, somewhat schistose, form the footwall of the dike.

\section{MENDENHALL GROUP.}

The Mendenhall group consists of six claims extending end to end, situated on the northwest side of Mendenhall Glacier near its foot. The main developments consist of an open cut 30 feet wide and a crosscut tunnel 85 feet long that attains a depth of 30 feet beneath the outcrop.

The ore body is a stringer lode that reaches a probable width of 100 feet, 30 feet of which is exposed in the open cut and 70 feet or more in the tunnel. The lode consists of a belt of black slates interbedded with green chloritic calc schists, which are penetrated by numerous veinlets of quartz. The rocks strike N. $25^{\circ} \mathrm{W}$. and dip vertically; the veinlets, which average a few inches in thickness, commonly trend parallel to the structure, but break across the beds irregularly from place to place. The veinlets àre sparsely mineralized with pyrrhotite, arsenopyrite, and galena; the slate adjoining the stringers is in places considerably impregnated with sharply defined crystals of arsenopyrite.

The stringers that cut the strata of chloritic schist differ from the others in that they consist of quartz, calcite, and albite, the albite being distinguishable from the other minerals by its twinning seams. 
The green schist is found under the microscope to consist essentially of calcite and chlorite with subordinate albite, biotite, and metallic sulphides. The rock as a whole has undoubtedly been strongly affected by vein-forming solutions, and the presence of the biotite seems to be due to this action.

Another prospect of greatly different character is situated on the Mendenhall claim. The ore consists of the mineralized portions of a massive amphibolite dike. The unmineralized and unaltered amphibolite is a heavy dark olive-green rock carrying numerous small black idiomorphic crystals of what appears to be augite, but proves when examined microscopically to be actinolite. In places the dike is irregularly cut by veinlets of albite and calcite, and the green amphibolite is transformed into a fine-grained black rock carrying, a small amount of pyrrhotite. At the main open cut about 15 feet of such rock is exposed; free gold can be panned here. The dike is 100 feet wide and lies parallel to the inclosing slates; much of it is exposed on bare glaciated surfaces, and it is obvious that only a small portion of the whole dike is auriferous rock. The chemical changes accompanying the introduction of the ore are discussed on page 39.

\section{DORAN PROSPECT.}

The Doran prospect is situated a short distance back from Gastineau Channel between Lemon and Salmon creeks. The work done consists of a 100-foot tunnel at an elevation of 550 feet and a drift following the mineral deposit for 30 feet. The lode under exploration consists of a dike of albite diorite, which is irregularly shattered and sheared and is considerably altered by mineralizing solutions. It is traversed by pyritic veinlets composed of quartz, albite, and carbonates. Albite is about as common in this prospect as quartz is in the ordinary prospect. The width of the dike is not satisfactorily shown.

A claim's length farther south is another tunnel, 180 feet long, driven to crosscut a similar ore body. Similarly isolated exposures at the north suggest that the dike, or perhaps one or more parallel dikes, continue through to Lemon Creek, where a thick outcrop of albite diorite is exposed at the mouth of the lower canyon. Small returns were obtained here, so that further investigation was discouraged, but, as shown by the presentation of the systematic assays of the ores of the Treadwell lode, a few samples are insufficient to determine the value of an extensive low-grade ore body. ${ }^{1}$ 


\section{INDEX.}

Alaska-Washington property, development and ore of..................... 48-49

Albite diorite, analyses, character, and distribution of .................... 27-29

Albitization, nature and origin of.......... 37-41

Amphibolite, from Mendenhall Glacier, analysis of.

from Port Snettisham, analysis of....... $\Lambda$ mphibolite dikes, character and occurrence of. Augite melaphyre, character and occurrence of ......................... 18-20

Aurora Borealis prospect, development and ore of........................ 47-48

Berners formation, character and distribution of ........................... 15-18

correlation of...................... 17-18

petrographic character of.............. 16-17

Bessie prospect, development and ore of..... 48

Black Chief lode, development on........ 51

Boston mine, Juneau, albite diorite from,

Brooks, A. H., preface by .................

California prospect, development and ore bodies of.................... 46-47

Canyon Creek prospects, development of. ... 50-51

Cascade lode, development of. .

50

Climate, general features of............... 10-11

Development of Eagle River region, account

of.......................... $8-9$

Dikes, character and occurrence of......... 27-33

Diorite porphyry, character and distribution of.............................. 30-31

Dividend lode, development on........... 49-50

tunnel on, cross-section showing - .......

Doran prospect, development and ore of.....

Dull \& Stephens prospect, development and ore of.

Eagle River, head of, plate showing.........

Eagle River mine, development and ore bodies of..................... 44-46

Eagle River region, geography of.......... 9-11 geologic map of................... In pocket geology and ore deposits of .............. 13-44 glaciation in ......................... 11-13

history and development of............ 8 $8-9$

location of ............................. 9

mining properties of ................ 44-60

physical features of................... 10

topographic map of ................ In pocket

vegetation and climate of.............. 10-11

Economic geology, account of.............. 34-44

E Pluribus Unum claim, development of... 50-51

Fairchild, J. G.; analyses by............. 28,39, 40

Fissure veins, character and occurrence of. .. 35

Forestation, character of ................... . 11

Fossils, of Quaternary deposits, forms of..... 33

Geography; account of................... 9-11

Geology, descriptive, account of........... 15-33
Page.

Geology, outline of. ................. 13-15

Glaciation, extent and character of......... 11-13

Goat Creek and Glacier, plate showing....... 10

Intrusions, minor, character of.............. 27-33

Juneau gold belt, ore deposits in northern portion of, map showing......... 34

Lamprophyric dikes, character and distribution of .................... 31-32

Mendenhall Glacier, plate showing ......... 12 Mendenhall group, development and ore of.. 59-60

Metasomatic processes, character of......... 36-41

Mineralized dikes, character and occurrence of............................. 36

Mines, detailed descriptions of ............ 44-60

Mining development, account of........... 8-9

Minor intrusions, character of............... 27-33

Mitchell \& McPherson property, development and ore of................ 53

Montana basin prospects, development of.... 55

Oleson prospect, development and ore of.... 51-52

Ore deposits, character, occurrence, and origin of......................... 34-44

general conclusions regarding........... 43-44

general features of.................... 13-15

map showing distribution of............ 34

origin of ............................. $41-43$

Patton claim, development and ore of ....... 55

Peterson property, development of ......... 53-54

Physical features, account of................ 10

Port Snettisham, amphibolite from, analysis of..............................

Prairie claim, development and ore of $\ldots$ section across strike at.................. 54

Precipitation, table showing............... 10 Quartz diorite gneiss, character, marginal features, and petrography of..... 23-27 Quaternary deposits, character and fossil deposits of...................... 32-33

St. Louis claim, development and ore of.... 52

Schists, character, occurrence, and origin of.. 20-23 Smith \& Heid property, development of..... $\quad 55$

Steamships, service of ...................... 9

Steiger, George, analysis by................ 28

Stringer lodes, character and occurrence of... 34-35

Summit claim, development and ore of...... 52

Temperatures, data regarding............. 10

Transportation, facilities for................ 9

Treadwell mine, Douglas Island, albite diorite from, analysis of............... 28

Treasury Hill claims, development and ore of. $55-58$ map showing........................ 56

Volcanic rocks, distribution, character, and petrographic features of.......... 18-20

Water power, availability of............... 11 Wiley \& Spaulding property, development and ore of .................. 55-58

Winn prospect, development and ore of...... $\quad 59$

Yankee Basin prospects, development of.... 49-50

Yankee Boy prospect, development of...... 51 






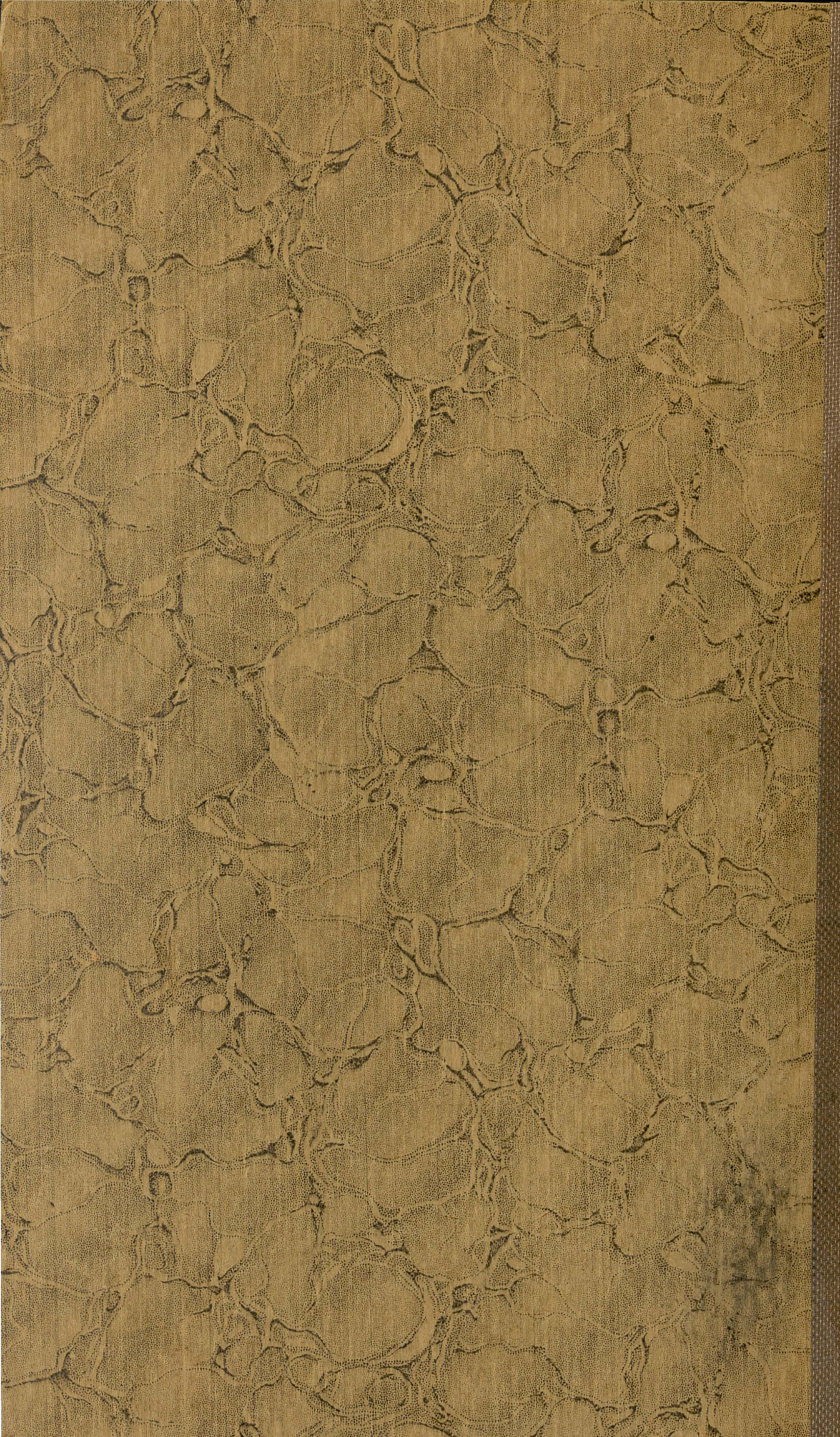

